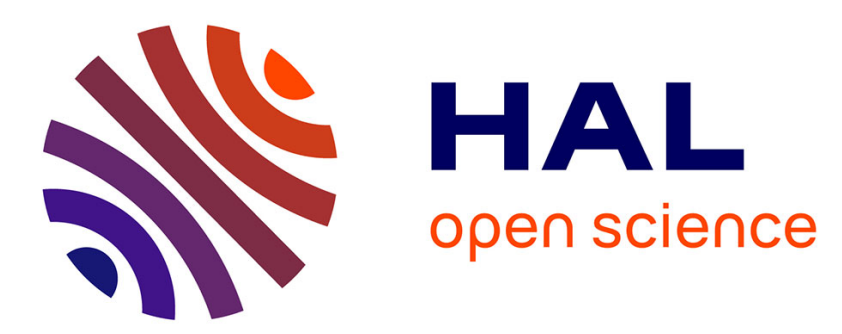

\title{
New Polyaminoisoprenyl Antibiotics Enhancers against Two Multidrug-Resistant Gram-Negative Bacteria from Enterobacter and Salmonella Species
}

Jean Michel Brunel

\section{- To cite this version: \\ Jean Michel Brunel. New Polyaminoisoprenyl Antibiotics Enhancers against Two Multidrug-Resistant Gram-Negative Bacteria from Enterobacter and Salmonella Species. Journal of Medicinal Chemistry, 2020, 63 (18), pp.10496-10508. 10.1021/acs.jmedchem.0c01335 . hal-03085044}

\section{HAL Id: hal-03085044 \\ https://hal.science/hal-03085044}

Submitted on 21 Dec 2020

HAL is a multi-disciplinary open access archive for the deposit and dissemination of scientific research documents, whether they are published or not. The documents may come from teaching and research institutions in France or abroad, or from public or private research centers.
L'archive ouverte pluridisciplinaire HAL, est destinée au dépôt et à la diffusion de documents scientifiques de niveau recherche, publiés ou non, émanant des établissements d'enseignement et de recherche français ou étrangers, des laboratoires publics ou privés. 


\title{
New polyaminoisoprenyl antibiotics enhancers against two multidrug resistant Gram- negative bacteria from Enterobacter and Salmonella species
}

\author{
Aurélie Lieutaud ${ }^{1}$, Cyril Pieri ${ }^{1}$, Jean Michel Bolla ${ }^{1 *}$ and Jean Michel Brunel ${ }^{1 *}$ \\ ${ }^{1}$ Aix Marseille Univ, INSERM, SSA, MCT, 13385 Marseille, France.
}

Keywords : Gram-negative bacteria, Multi-drug resistance, Efflux pump, Antibiotic enhancers, Polyaminoisoprenyl derivatives.

\begin{abstract}
A series consisting of new polyaminoisoprenyl derivatives were prepared in moderate to good chemical yields varying from 32 to $64 \%$ according two synthetic pathways: 1) using a titanium reductive amination reaction affording a 50/50 mixture of cis and trans isomers 2) a direct nucleophilic substitution leading to a stereoselective synthesis of the compounds of interest. These compounds were then successfully evaluated for their in vitro antibiotic enhancer properties against resistant Gram-negative bacteria of four antibiotics belonging to four different families. The mechanism of action against Enterobacter aerogenes of one of the most efficient of these chemosensitizing agents was precisely evaluated by using fluorescent dyes to measure outer-membrane permeability and to determine membrane depolarization. The weak cytotoxicity encountered led us to perform an in vivo experiment dealing with the treatment of mice infected with Salmonella Typhimurium and affording preliminary promising results in terms of tolerance and efficiency of the polyaminoisoprenyl derivative $5 \mathbf{r} /$ doxycycline combination.
\end{abstract}




\section{Introduction}

Over the last decades, antibiotic resistance has become one of the predominant general health concerns principally due to the overuse of antibiotics, the ageing of the population mostly subjected to infections, the increase of efficiency of intensive care units taking in charge patients in decreased physiological state. ${ }^{1-3}$ In this context and closely associated to the failure in the discovery of new antibiotics, there is a need to improve all the stages of infectious diseases treatments including the management of different steps of antibiotic usage and the improvement of the efficiency of well-known antibiotics. ${ }^{4-5}$ Amongst the human pathogenic bacteria, the ESKAPE group (Enterococcus faecium, Staphylococcus aureus, Klebsiella pneumoniae, Acinetobacter baumannii, Pseudomonas aeruginosa, Enterobacter spp) first described by Rice et al., is the most problematic for the clinicians because of their ability to evade and escape common therapies. ${ }^{6}$ This ESKAPE group was further considered as of major importance by the $\mathrm{WHO} .^{7}$ On the other hand, bacteria may be intrinsically resistant or may acquire resistance by de novo mutation or via the acquisition of resistance genes from other organisms. Furthermore, acquired resistance mechanisms permit to a bacterium to produce enzymes able to destroy the drug, to produce target protection proteins that prevent the drug binding, the expression of efflux systems that avoid the drug to reach its intracellular target, the target site modification, the production of an alternative metabolic pathway to circumvent the action of the drug. Thus, efflux mechanisms constitute important determinants of resistance to antibiotics in human pathogens. ${ }^{8-11}$ Additionally, susceptible Gram-negative bacteria can become resistant particularly by changing the permeability of their membranes or by reducing the number of channels available for drugs to diffuse through. ${ }^{12-13}$ Given the clinical significance of antimicrobial exporters ${ }^{9}$, it is clear that efflux must be considered in formulating strategies for treatment of drug-resistant infections, by the development of new agents less impacted by efflux or by targeting efflux directly with efflux inhibitors restoring the activity of 
several drugs on acquired MultiDrugResistant (MDR) bugs and also allowing the susceptibility of drugs on naturally resistant bacteria. ${ }^{14}$

In this context, we have previously reported the ability of a natural compound, namely geraniol, to decrease the antibiotic resistance of a Gram-negative MDR Enterobacteria strain. ${ }^{15}$ This compound has been determined to be a substrate of the AcrAB-TolC pump and conjointly inhibiting the transport of other molecules including antibiotics by this pump. ${ }^{16}$ Furthermore, we recently reported the synthesis of polyaminogeranic acid derivatives and their efficient use as new chemosensitizers inducing a significant decrease of antibiotic resistance in Gramnegative bacterial MDR strains. ${ }^{17}$ On the other hand, we were also able to demonstrate that water-soluble geraniol parent amino derivative, geranylamine as well as NV716 was effective as an efflux pump inhibitor (Figure 1). ${ }^{18-19}$

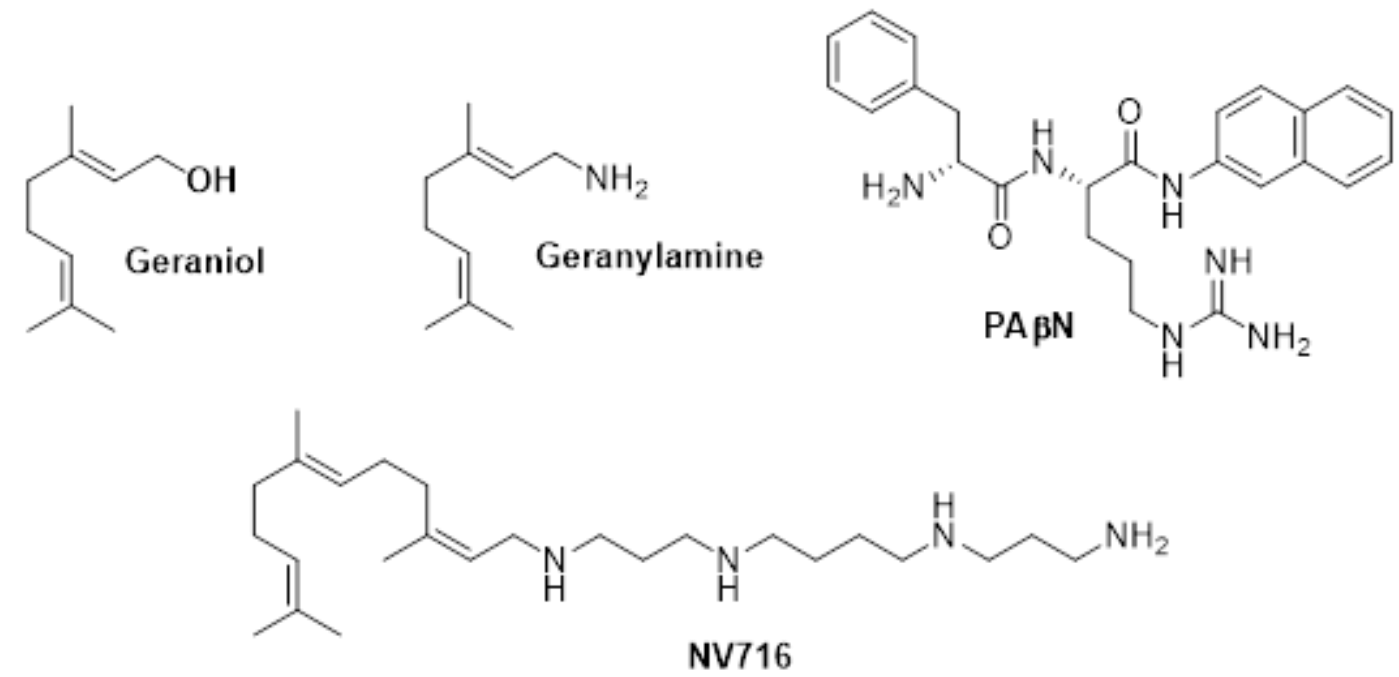

Figure 1. Structure of Geraniol, Geranylamine, PA $\beta N$ and NV716

In this context, we will report herein the synthesis, biological evaluation, and structure activity relationships analysis of a series of new polyaminoisoprenyl antibiotic enhancers against multidrug resistant Gram-negative bacteria Enterobacter aerogenes and Salmonella enterica serovar Typhimurium.

\section{Results and discussion}




\section{Chemistry}

Using an efficient titanium reductive amination developed in our laboratory ${ }^{20-21}$, we have envisioned a one-step synthesis procedure for the preparation of new polyaminoisoprenyl derivatives in a $\mathrm{Z} / \mathrm{E}$ mixture from both citral and farnesal according to the following synthetic pathway (Table 1).

Table 1. Titanium (IV) reductive amination reaction of citral with spermine under various experimental conditions.

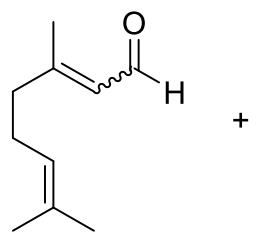

1<smiles>NCCCNCCCCNCCCN</smiles>

2

\begin{tabular}{cccc}
\hline Entry & $\begin{array}{c}\text { Titanium } \\
\text { source }\end{array}$ & Solvent & Yield $(\%)^{\mathrm{c}}$ \\
\hline $1^{\mathrm{a}}$ & $\mathrm{Ti}(\mathrm{O} i-\mathrm{Pr})_{4}$ & $\mathrm{MeOH}$ & 64 \\
$2^{\mathrm{b}}$ & $\mathrm{Ti}(\mathrm{O} i-\mathrm{Pr})_{4}$ & $\mathrm{MeOH}$ & 51 \\
$3^{\mathrm{a}}$ & $\mathrm{Ti}(\mathrm{O} i-\mathrm{Pr})_{4}$ & $\mathrm{CH}_{2} \mathrm{Cl}{ }_{2}$ & 30 \\
$4^{\mathrm{a}}$ & $\mathrm{Ti}(\mathrm{O} i-\mathrm{Pr})_{4}$ & Toluene & 19 \\
$5^{\mathrm{a}}$ & $\mathrm{Ti}(\mathrm{O} i-\mathrm{Pr})_{4}$ & $\mathrm{THF}$ & 33 \\
$6^{\mathrm{a}}$ & $\mathrm{Ti}(\mathrm{OEt})_{4}$ & $\mathrm{MeOH}$ & 39 \\
$7^{\mathrm{a}}$ & $\mathrm{Ti}(\mathrm{OBu})_{4}$ & $\mathrm{MeOH}$ & 30 \\
$8^{\mathrm{a}}$ & $\mathrm{Ti}(\mathrm{O} t-\mathrm{Bu})_{4}$ & $\mathrm{MeOH}$ & 21
\end{tabular}

${ }^{\text {a }}$ Reaction performed at $-78^{\circ} \mathrm{C}$ for $12 \mathrm{~h}$ in $\mathrm{MeOH}$ on a 0.39 mmol scale of citral, $\mathrm{Ti}(\mathrm{O} i \text { - } \mathrm{Pr})_{4}(2.02 \mathrm{mmol})$ and the amine $(6$ mmol). ${ }^{b}$ Reaction performed at $0{ }^{\circ} \mathrm{C}$. ${ }^{\mathrm{c}}$ Isolated overall yield.

First, it clearly appears that isolated yields of compound 5p are highly solvent-dependent. Thus, the expected amino derivative $\mathbf{5 p}$ was obtained in $64 \%$ yield performing the reaction in $\mathrm{MeOH}$ (Table 1, entry 1), whereas only moderate yields varying from 19-33\% were encountered performing the reaction in $\mathrm{CH}_{2} \mathrm{Cl}_{2}$, toluene and THF, respectively (Table 1, entries 3-5). Influence of the nature of the titanium source involved was also investigated and chemical yield variations from 21 to $64 \%$ were obtained (Table 1, entries 1, 6-8), best result being observed using $\operatorname{Ti}(\mathrm{O} i \text {-Pr })_{4}$ as titanium source. Furthermore, under these best experimental conditions, 
increasing of the reaction temperature from -78 to $0^{\circ} \mathrm{C}$ led to a slight decrease of the chemical yield encountered from 64 to $51 \%$, respectively (Table 1, entries 1 and 2).

Under the best experimental conditions (Table 1, entry 1), we have envisioned the use of numerous different natural (such as cadaverine, putrescine, spermine...) or synthetic polyamines in the titanium reductive amination of citral and farnesal and the results are summarized in Table 2.

Table 2. Polyaminoisoprenyl derivatives obtained from citral (5a-5r) or farnesal (6a-6r).

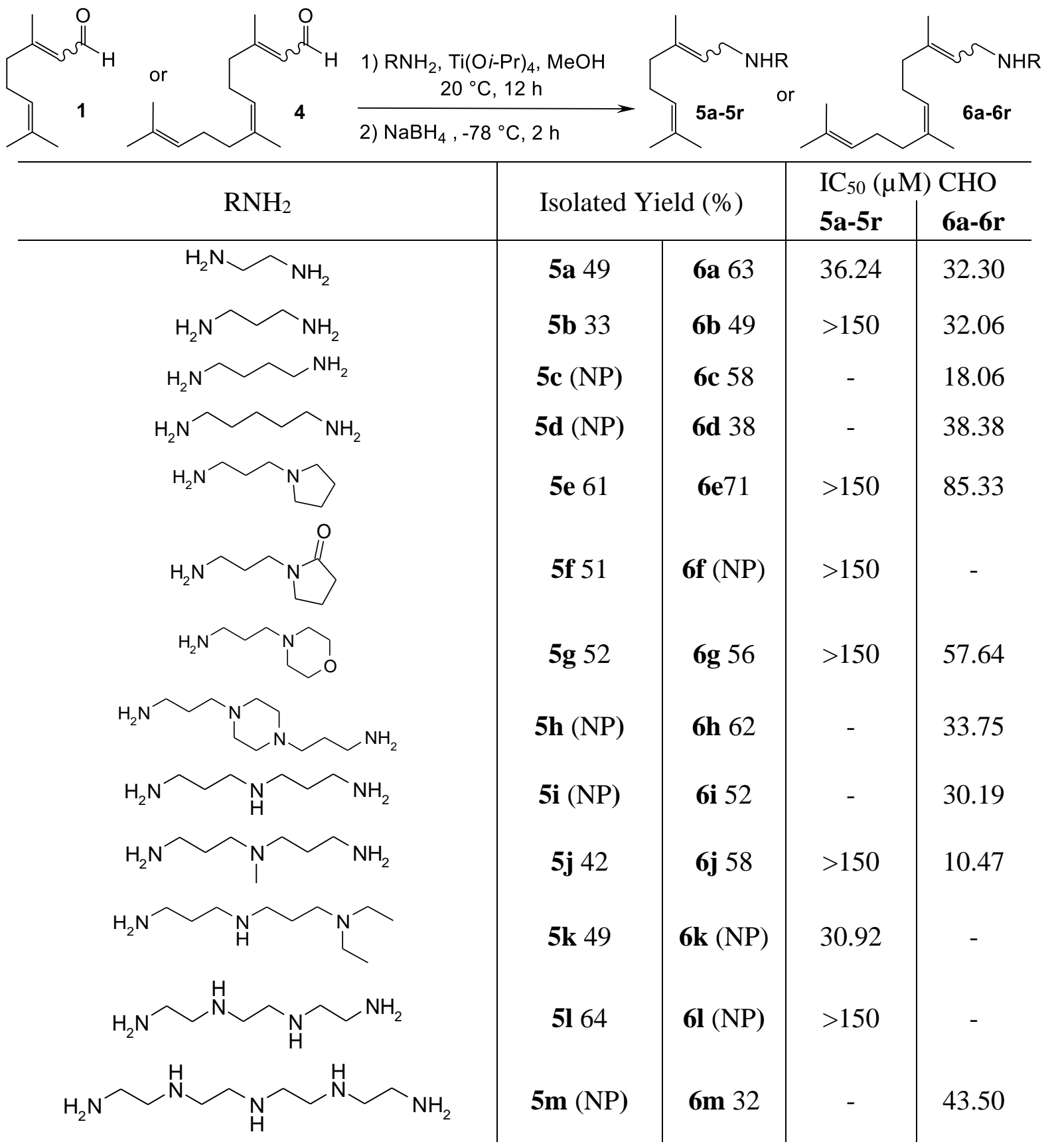




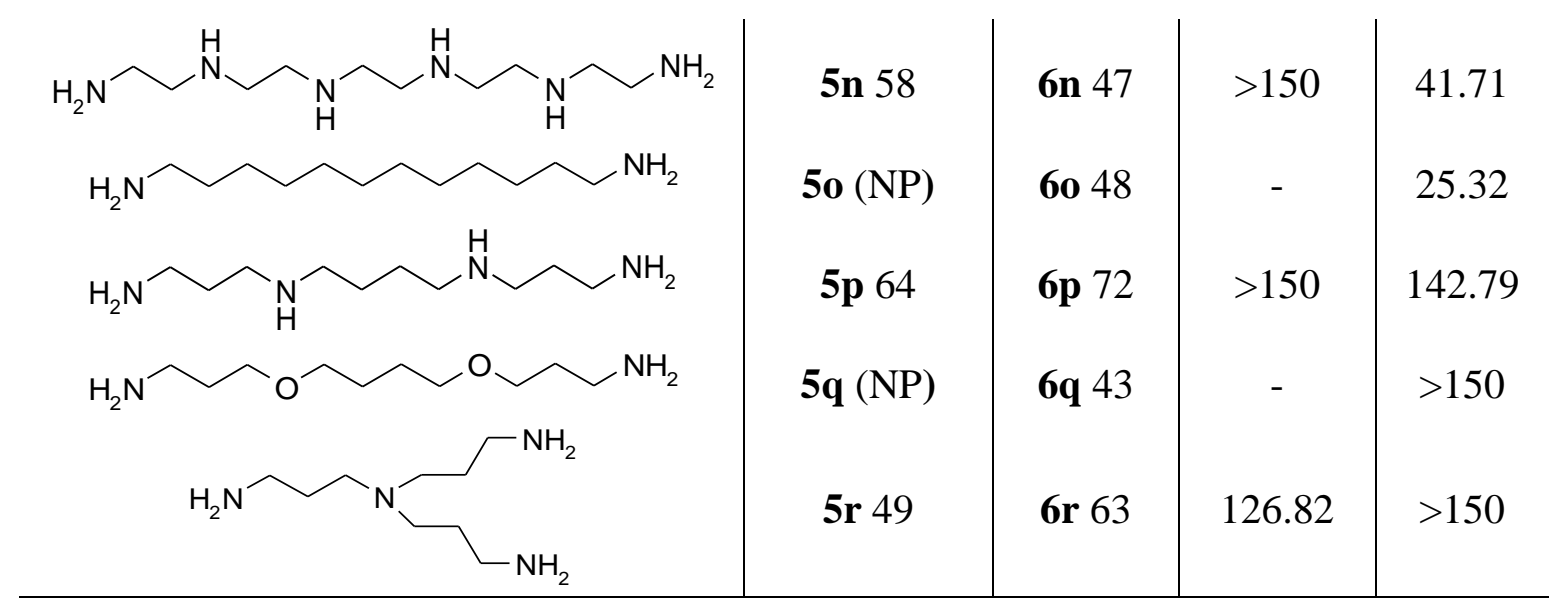

NP : not prepared

Whatever the nature of the amines, the expected polyaminoisoprenyl products were obtained mixture of the $Z / E$ isomers in a 50/50 ratio in moderate to good chemical yields varying from 32 to $72 \%$. It is noteworthy that these reactions have not been yet optimized, the moderate results being explained by the difficulty to purify the expected polar products.

\section{Antimicrobial activities}

In the context of our studies, all the synthesized compounds were firstly screened for their antimicrobial activity against Gram-negative bacterial strains (Table S-1). Two pairs of enterobacterial strains were challenged, one E. aerogenes MDR strain Ea289 over-expressing the efflux pump AcrAB-TolC and its $\triangle a c r B$ mutant, and one $S$. Typhimurium MDR strain BN10055 over-expressing the same efflux pump and its $\Delta a c r B$ mutant. The data presented in Table S-1 demonstrated that the MICs of the polyaminoisoprenyl derivatives vary from a maximum of over $500 \mu \mathrm{M}$ for $\mathbf{5 l}$ and $\mathbf{5 n}$ against the four strains to a minimum of $7.8 \mu \mathrm{M}$ for compounds 6n and $\mathbf{6 0}$ against the Enterobacter strain Ea289 $\triangle a c r B$, and $3.9 \mu \mathrm{M}$ for $\mathbf{6 0}$ against Salmonella strain BN10055 $\triangle a c r B$. Additionally, except for 60 no significant differences are noticed against both Salmonella strains indicating that none of the compounds is a substrate of the efflux pump AcrAB-TolC. 
In this study, our goal was to identify molecules capable of decreasing antibiotic resistance of Gram-negative MDR strains. Thus, we chose drugs for which these strains had high MIC values and our compounds were tested for their ability to decrease resistance of the MDR strains to erythromycin, doxycycline, nalidixic acid and chloramphenicol in a synergistic assay. The compounds were used at a sub-inhibitory concentration corresponding to a quarter of their respective MICs to avoid an intrinsic action and to ascertain that the effect observed resulted from the combination of the molecules used. For the two MDR strains EA289 and BN10055 we determined the ratio between the MIC of each antibiotic when applied alone and the MIC of the antibiotic in the presence of a desired compound. The cumulative MIC ratios for each compound are presented in Figure 2A and 2B, respectively. 

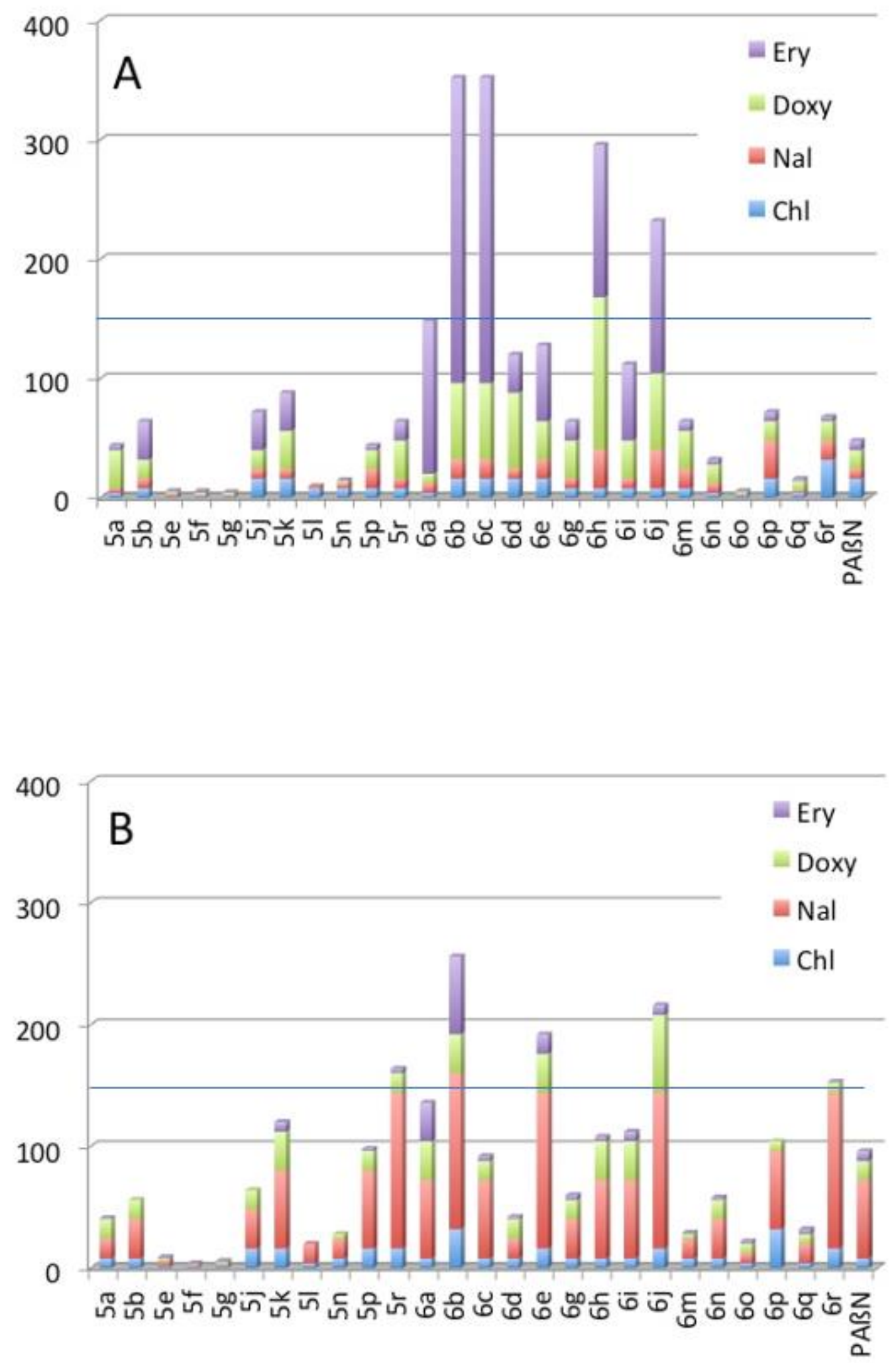

Figure 2. Cumulative MIC ratios for each compound for their ability to decrease resistance of MDR strains EA289 (Figure 2A) and BN10055 (Figure 2B) to erythromycin, doxycycline, nalidixic acid and chloramphenicol in a synergistic assay. 
Although three compounds (5e, 5f, and 5g) are ineffective, the twenty-three other ones exhibited an efficiency at least in one of the combinations with the antibiotics. In the case of Enterobacter, 4 compounds $(\mathbf{6 b}, \mathbf{6 c}, \mathbf{6 h}, \mathbf{6 j})$ showed a cumulative score over 150 (Figure 2A) while 5 others $(\mathbf{6 b}, \mathbf{6 j}, \mathbf{6 e}, \mathbf{5 r}, \mathbf{6 r})$ had the same behavior in the case of Salmonella (Figure 2B). In this context, the data of Figure $2 \mathrm{~A}$ and $2 \mathrm{~B}$ highlighted that $\mathbf{6 b}$ and $\mathbf{6} \mathbf{j}$ are the most efficient and promising compounds.

We also observed, that several compounds decreased the MIC of the antibiotic under the threshold of susceptibility according to the Comité de l'Antibiogramme de la Société Française de Microbiologie (CA-SFM) ${ }^{22},(\leq 2 \mathrm{mg} / \mathrm{L}$ for the four antibiotics tested) (Table 3).

Table 3: Decrease of chloramphenicol, nalidixic acid, doxycycline and erythromycin resistance in the presence of the polyaminoisoprenyl enhancers 5a-6r.

\begin{tabular}{|c|c|c|c|c|c|c|c|c|}
\hline \multirow{3}{*}{ Adjuvant } & \multicolumn{8}{|c|}{ Gain factor ${ }^{\mathrm{a}}$} \\
\hline & \multicolumn{4}{|c|}{ Ea289 } & \multicolumn{4}{|c|}{ BN10055 } \\
\hline & Chl & $\mathrm{Nal}$ & Doxy & Ery & Chl & $\mathrm{Nal}$ & Doxy & Ery \\
\hline $\mathrm{No}^{\mathrm{b}}$ & 1024 & 4096 & 32 & 256 & 1024 & 4096 & 64 & 256 \\
\hline $5 a$ & 4 & 4 & 32 & 4 & 8 & 16 & 16 & 1 \\
\hline $5 b$ & 8 & 8 & 16 & 32 & 8 & 32 & 16 & \\
\hline $5 e$ & 1 & 2 & 2 & 1 & 2 & 4 & 2 & 1 \\
\hline $5 f$ & 1 & 1 & 2 & 2 & 1 & 1 & 1 & 1 \\
\hline $5 \mathrm{~g}$ & 1 & 1 & 2 & 1 & 2 & 1 & 2 & 1 \\
\hline $5 j$ & 16 & 8 & 16 & 32 & 16 & 32 & 16 & $\mathrm{Nd}$ \\
\hline $5 \mathrm{k}$ & 16 & 8 & 32 & 32 & 16 & 64 & 32 & 8 \\
\hline 51 & 8 & 2 & $\mathrm{Nd}^{\mathrm{c}}$ & $N d^{c}$ & 4 & 16 & $\mathrm{Nd}^{\mathrm{c}}$ & $\mathrm{Nd}^{\mathrm{c}}$ \\
\hline $5 n$ & 8 & 4 & 2 & 1 & 8 & 16 & 4 & $\mathrm{Nd}^{\mathrm{c}}$ \\
\hline $5 p$ & 8 & 16 & 16 & 4 & 16 & 64 & 16 & 2 \\
\hline $5 r$ & 8 & 8 & 32 & 16 & 16 & 128 & 16 & 4 \\
\hline $6 a$ & 4 & 8 & 8 & 128 & 8 & 64 & 32 & 32 \\
\hline $6 b$ & 16 & 16 & 64 & 256 & 32 & 128 & 32 & 64 \\
\hline $6 c$ & 16 & 16 & 64 & 256 & 8 & 64 & 16 & 4 \\
\hline $6 d$ & 16 & 8 & 64 & 32 & 8 & 16 & 16 & 2 \\
\hline $6 e$ & 16 & 16 & 32 & 64 & 16 & 128 & 32 & 16 \\
\hline $6 \mathrm{~g}$ & 8 & 8 & 32 & 16 & 8 & 32 & 16 & 4 \\
\hline $6 h$ & 8 & 32 & 128 & 128 & 8 & 64 & 32 & 4 \\
\hline $6 i$ & 8 & 8 & 32 & 64 & 8 & 64 & 32 & 8 \\
\hline
\end{tabular}




\begin{tabular}{c|cccc|cccc}
$\mathbf{6 j}$ & 8 & 32 & 64 & 128 & 16 & 128 & 64 & 8 \\
$\mathbf{6 m}$ & 8 & 16 & 32 & 8 & 8 & 16 & 4 & 1 \\
$\mathbf{6 n}$ & 4 & 8 & 16 & 4 & 8 & 32 & 16 & 2 \\
$\mathbf{6 0}$ & 2 & 1 & 2 & 1 & 4 & 8 & 8 & 2 \\
$\mathbf{6 p}$ & 16 & 32 & 16 & 8 & 32 & 64 & 8 & $\mathrm{Nd}^{c}$ \\
$\mathbf{6 q}$ & 4 & 2 & 8 & 2 & 4 & 16 & 8 & 4 \\
$\mathbf{6 r}$ & 32 & 16 & 16 & 4 & 16 & 128 & 8 & 1 \\
PABN & 16 & 8 & 16 & 8 & 8 & 64 & 16 & 8 \\
\hline
\end{tabular}

${ }^{a}$ Gain factor determined as the ratio of the MIC of the antibiotic alone for each strain to the MIC of the same antibiotic in the presence of the considered compound at a concentration corresponding to its $\mathrm{MIC} / 4$. A gain factor greater than 1 indicates an improvement of activity. ${ }^{\mathrm{b}}$ MIC determined for the antibiotics alone. ${ }^{\mathrm{c}} \mathrm{Nd}$, Not determined.

This is particularly the case against Ea289 for most compounds in combination with doxycycline. Concerning erythromycin five compounds were observed to decrease the MIC of Ea289 under the threshold. To a lesser extent, the same observations can be drawn for the combination of seven compounds and doxycycline against Salmonella. Noticeably, derivatives $5 \mathbf{k}, 6 \mathbf{b}, \mathbf{6 e}, \mathbf{6 h}, \mathbf{6 i}$ and $\mathbf{6 j}$ decrease the MIC of doxycycline towards these two strains. Surprisingly, whereas these compounds in the presence of erythromycin led to an efficient combination against Enterobacter, none of these significantly improve the MIC of erythromycin against Salmonella.

Taken together these results suggested that the two compounds $\mathbf{6 b}$ and $\mathbf{6 j}$ might be the most active. However, this analysis did not consider the concentration used to get the synergy with the different antibiotics. Consequently, in order to generate comparable data we decided to correlate the efficiency according to the concentration used by introducing an "Efficiency Parameter" (EP) that corresponds to the sum of gain for each compound obtained for the four antibiotics tested and divided by the concentration of the molecule used in the assay (Table $\mathrm{S}$ 2). It is noteworthy that the gain factor was defined as corresponding to the ratio of the MIC of the antibiotic tested alone to the MIC of the antibiotic obtained in the presence of the considered adjuvant. 
This EP varies from 0.01 to 7.17 in arbitrary units allowing us to classify the compounds into three groups: one group corresponding to non-efficient molecules, a second group with molecules with an average score of EP varying from 0.01 to 0.57 and a third one with an EP higher than 1 and reaching 7.17 in the best case (Table S-2).

It is noticeable that PAßN, the reference inhibitor of Gram-negative efflux has through this classification an efficiency of 0.47 making it part of the second group. The third group comprised 13 compounds including the three compounds previously identified. This third group appeared as the most efficient. To better characterize our compounds and considering this kind of molecules as putative drug adjuvants, the cytotoxicity of each molecule has been investigated.

Cytotoxicity was assayed with Chinese hamster ovary $(\mathrm{CHO})$ cells for all the compounds which present $\mathrm{IC}_{50}$ ranging from 1 to $150 \mu \mathrm{M}$. A major part of our compounds exhibited an $\mathrm{IC}_{50}$ comprised between 18.06 and $142.79 \mu \mathrm{M}$ while 10 compounds had $\mathrm{IC}_{50}$ over $150 \mu \mathrm{M}$ suggesting that they were minimally toxic. A toxicity index varying from 0.06 to 19.2 was subsequently defined as the ratio of $\mathrm{IC}_{50}$ to the concentration used leading to a decrease of MIC of at least 8 times. Thus, we were able to directly compare the EP of each compound versus its toxicity index as plotted in Figure 3. 


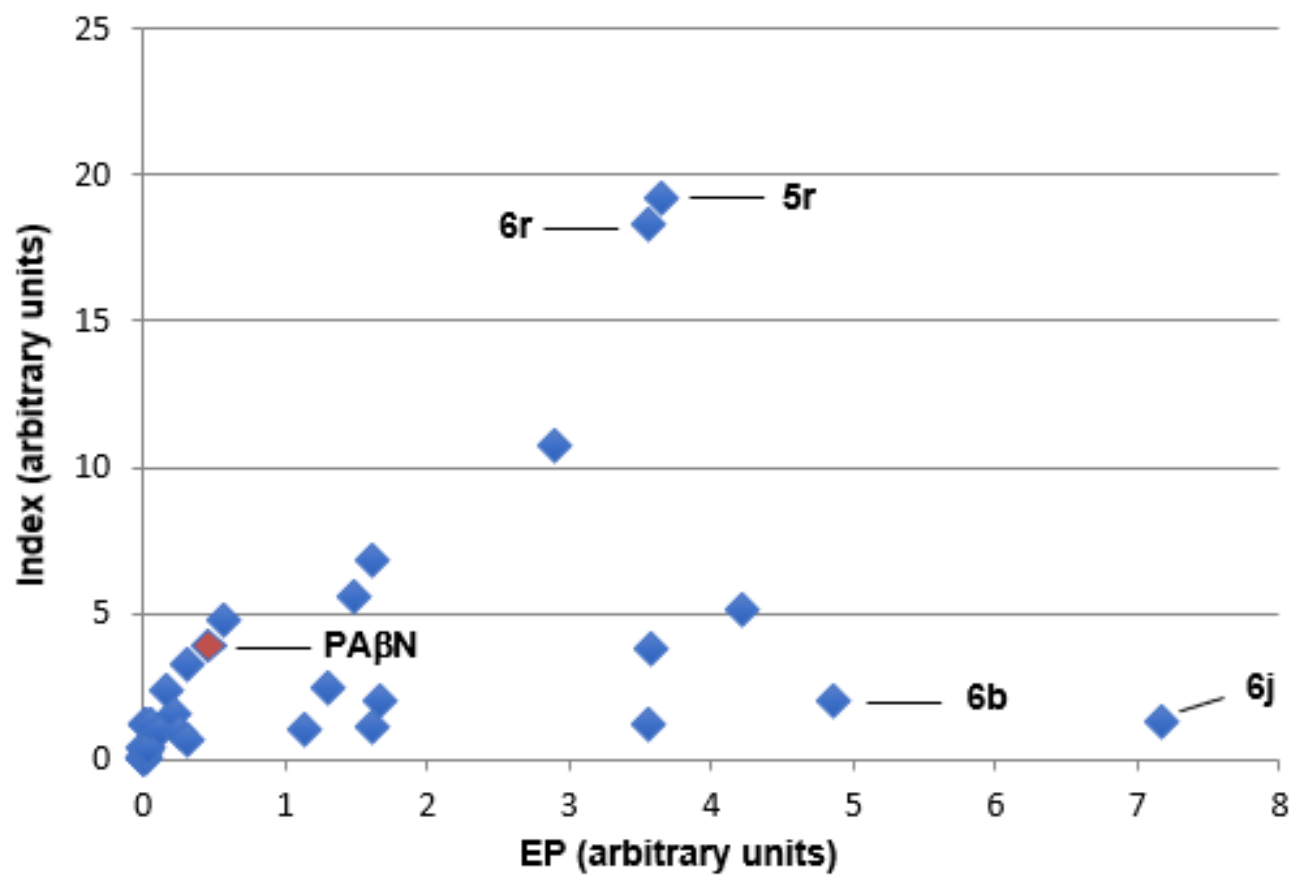

Figure 3. Efficiency/toxicity index correlation for all the polyaminoisoprenyl derivatives

It is noteworthy that two compounds $\mathbf{5 r}$ and $\mathbf{6 r}$ exhibited the best cytotoxicity index and $\mathbf{6 j}$ and 6b the best efficiency, respectively, and that they were used at similar concentration against the considered bacteria in order to compare their efficiency in the same range of concentration (see Table S-2). In this context, $5 \mathbf{r}$ and $\mathbf{6 r}$ showed efficiency index about 2 times lower than $\mathbf{6 j}$ but presented a better toxicity index. By comparison, PAßN (red dot on Figure 3) presented a moderate to weak efficiency index of 0.47 and a toxicity index of 3.95. Thus, six compounds namely $\mathbf{6 p}, \mathbf{6 r}, \mathbf{5 p}, \mathbf{5 r}, \mathbf{6 n}$, and $\mathbf{6 m}$ were identified to possess better parameters than PAßN. Additionally, $\mathbf{5 r}$ was identified as the most potent compound by considering all these criteria. We suppose, as already postulated by others ${ }^{23}$ that the death process could involve electrostatic interactions and is related to the high density of charges exposed at the surface of bacterial membranes. Thus, the electrostatic compensation of the negative charges of the bacterial envelope could be provided by the cationic charges of the substrate leading for the bacteria to a loss of their natural counterions. Based on the number of positive charges involved (number of nitrogen atoms present in the structure) the different compounds were classified and three groups of molecules emerged (Table 4). 
Table 4. Stucture-activity relationships analysis

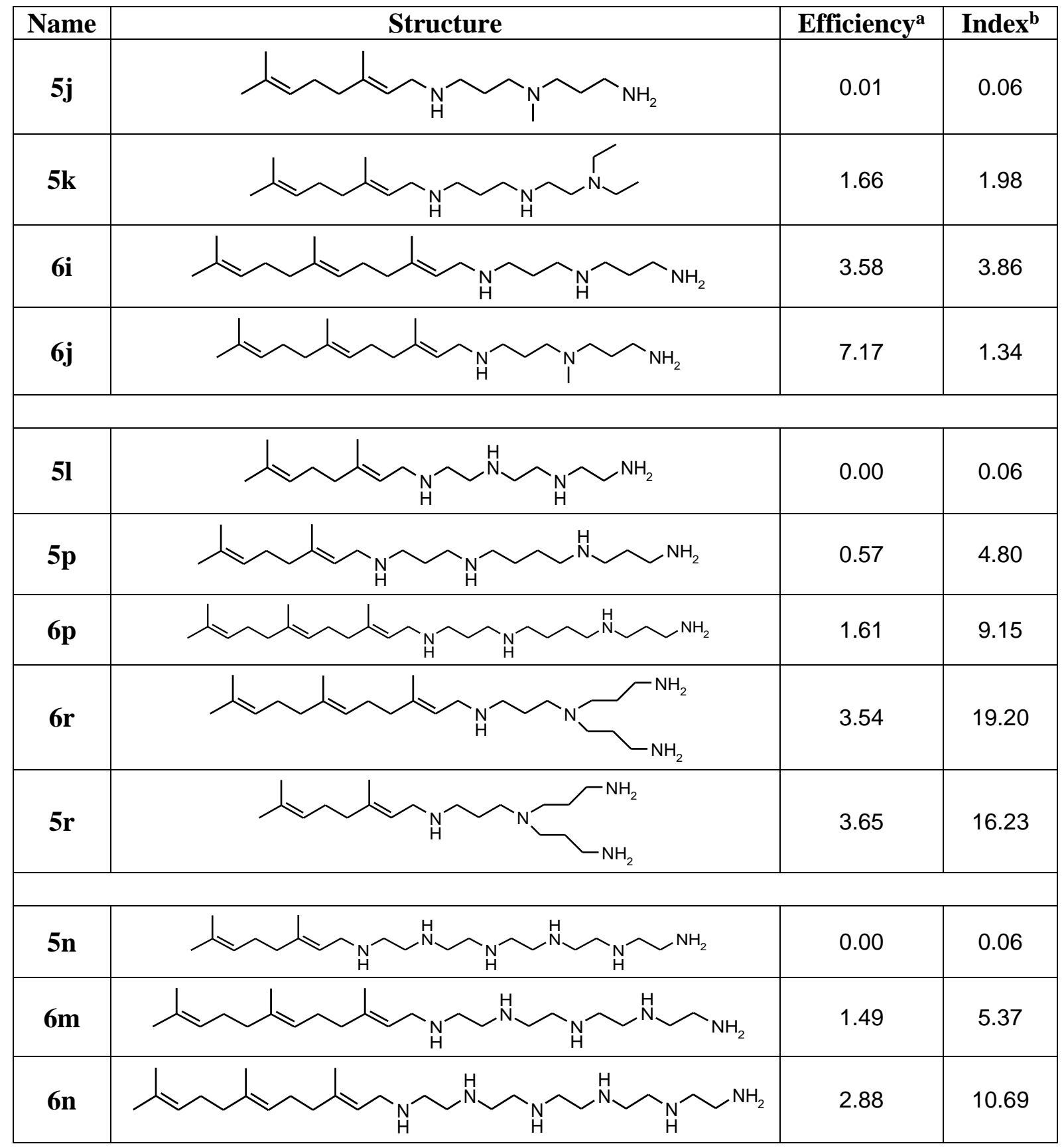

${ }^{a}$ Efficiency parameter that corresponds to the sum of gain factor for each compound reported for the four antibiotics tested and divided by the concentration of the molecule used in the assay. ${ }^{\mathrm{b}}$ Index parameter is determined by the ratio of the $\mathrm{IC}_{50}$ to the concentration giving a decrease of MIC of at least 8 times for almost 3 antibiotics on both species.

The most efficient compound $\mathbf{6 j}$ was encountered in the first group with an efficiency score of 7.17. This compound is a farnesyl derivative, with a triterpene structure linked to a linear triamine (three positive charges). Otherwise, the parent geranyl compound $\mathbf{5 j}$, was neither efficient nor showed a good index of toxicity indicating that the length of the terpene moiety is 
of major importance. While the activity of $\mathbf{6 i}$ is near half of the activity of $\mathbf{6 j}$, its index of toxicity is about 3 times higher suggesting that the nature of the amino-methyl group plays an important role for toxicity.

On the other hand, some compounds including four amino groups such as $\mathbf{6 r}$ and $\mathbf{5 r}$ in their close present interesting results in terms of activity and toxicity. By comparing $\mathbf{5 l}$ and $\mathbf{5 p}$ it clearly appears that the number of carbon atoms between the amino groups remains crucial on the outcome of the observed antimicrobial activities whereas the number of positive charges is conserved. Furthermore, comparison of the structure for derivatives $\mathbf{6 p}$ and $\mathbf{5 p}$ lead to the conclusion that the length of the terpene chain involved is of major importance for the activity encountered whereas the polyamine chain is conserved. Moreover, the presence of a ramified amine in compounds $\mathbf{6 r}$ and $\mathbf{5 r}$ improve their efficiency and toxicity index with respect to their parent derivatives $\mathbf{5 p}$ and $\mathbf{6 p}$ involving a linear spermine group. In the third group, the importance of the length of the terpene moiety with respect to the encountered efficiency was confirmed by studying typically derivatives $\mathbf{5 n}$ and $\mathbf{6 m}$. It is noteworthy that an attempt to correlate the efficiency or cytotoxicity of the different compounds with their intrinsic lipophilicity by considering the $\log \mathrm{P}$ parameter, which reflects the true behavior and bioavailability of an ionizable compound in a solution at a given $\mathrm{pH}$, failed (Table S-2).

All these derivatives have been prepared as a 50/50 mixture of cis and trans isomers. At this stage, it appears of interest to determine the impact of each isomer on the observed biological activities. In a first approach and due to its interesting biological data, the synthesis of pure $Z$ 5r and $E-5 \mathbf{r}$ derivatives has been envisioned with the use of a titanium amination reaction involving pure isomers of neral or geranial as starting materials.

Surprisingly, a subsequent titanium amination reaction in methanol in the presence of tris(3aminopropyl)amine 7 led to a mixture of the $Z / E$ isomers of $\mathbf{5 r}$ in a 50/50 ratio in a nonoptimized $35 \%$ isolated yield (Scheme 1$)$. 
<smiles>CC(C)=CCCC(C)C</smiles>

geranial Z-1 (90\% pure form)

1 equiv.

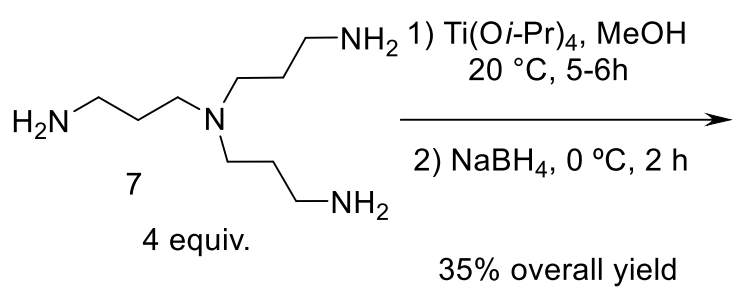

$35 \%$ overall yield

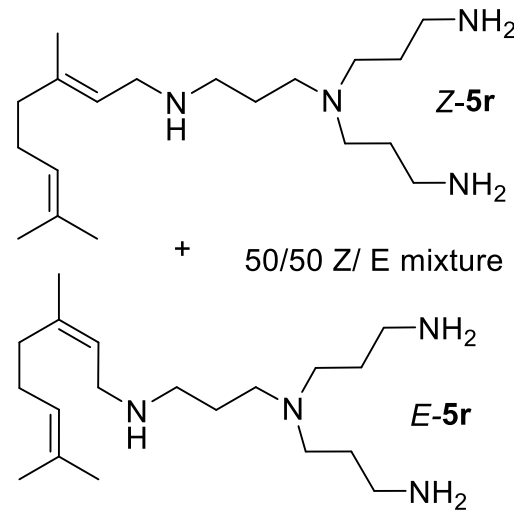

Scheme 1. Titanium reductive amination of geranial Z-1 with tris(3-aminopropyl) amine 7.

Thus, whatever the experimental conditions applied (data not shown) it was impossible to obtain the expected polyamino derivatives in a pure stereoselective form. We have been able to demonstrate that this racemization occurs by mixing the pure aldehyde and the amine in the absence of titanium isopropoxide. Indeed, after two days the corresponding imines were obtained as a mixture of the two isomers suggesting an isomerization process during the imine formation. ${ }^{24-30}$

These disappointing results led us to envision another strategy involving a direct nucleophilic substitution of the considered polyamine on geranyl chloride $\mathbf{8}$ and neryl chloride $\mathbf{9}$ derivatives (Scheme 2).<smiles>CC(C)=CCCC(C)=CCCl</smiles><smiles>CCCN(CCCN)CCCN</smiles>
$\mathrm{NEt}_{3}(2.2$ equiv.)<smiles>CC(C)=CCCC(C)=CCCl</smiles>
7 THF, $20^{\circ} \mathrm{C}, 24 \mathrm{~h}$<smiles>CC(C)=CCCNCCCN(CCCN)CCCN</smiles>
or<smiles>CC(C)=CCCNCCCN(CCCN)CCCN</smiles>

Scheme 2. Synthesis of pure Z-5r and E-5r by nucleophilic substitution of tris(3aminopropyl)amine $\mathbf{7}$ on geranyl chloride $\mathbf{8}$ and neryl chloride $\mathbf{9}$ derivatives. 
Under these experimental conditions, the expected products were obtained as pure isomers Z5r and $E-5 \mathbf{r}$ in 53 and $48 \%$ isolated yield, respectively. Their biological efficiency and cytotoxicity have been evaluated involving different salt formulations as summarized in Table S-3).

It clearly appears that no significant differences were obtained in terms of biological activities and cytotoxicity for the different isomers and formulations used.

\section{Animal study}

Because of these outcomes, we have used a mixture of $Z-5 \mathbf{r} / E-5 \mathbf{r}$ to investigate the potent mechanism of action of these derivatives against Gram-negative bacteria and evaluate their efficiency in a very preliminary in vivo animal model. Thus, to ascertain the in vivo activity of compound $\mathbf{5 r}$, mice were used as animal model to determine their tolerance to this compound as well as the in vivo activity of $\mathbf{5 r} /$ doxycycline combination against $S$. Typhimurium infection. ${ }^{31}$ In a first approach, the results indicate a good tolerance of the mice towards $\mathbf{5 r}$ to a concentration of $50 \mu \mathrm{M}$ and they did not show signs of acute toxicity (Figure 4A). On the other, the treatment by a doxycycline $/ \mathbf{5 r}$ combination $(64 \mathrm{mg} / \mathrm{Kg}$ for doxycycline and $0.5 \mathrm{mg} / \mathrm{Kg}$ for $\mathbf{5 r}$, respectively) of $S$. Typhimurium infected mice lead to a $43 \%$ survival rate whereas all the mice died by using a treatment involving saline solution or doxycycline alone as illustrated in Figure 4B.
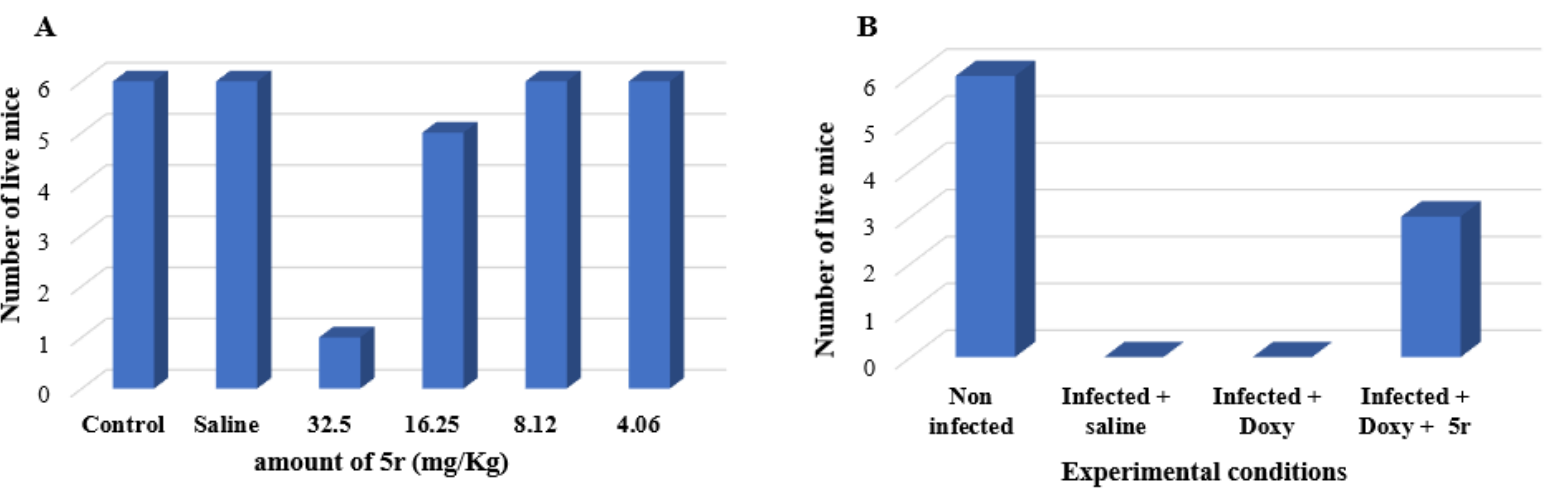

Figure 4. A) Mice survival 24h after administration with saline or 5r (4.06, 8.12, 16.25, 32.5 $\mathrm{mg} / \mathrm{Kg}$ ). B) Survival of mice infected with $S$. Typhimurium following administration with 
saline, doxycycline alone or a doxycycline/5r combination solution $(64 \mathrm{mg} / \mathrm{Kg}$ for doxycycline and $0.5 \mathrm{mg} / \mathrm{Kg}$ for $\mathbf{5 r}$, respectively). Survival of mice number corresponds to the number of mice euthanized.

These results, even if there are preliminary, tend to demonstrate the potent in vivo enhancing activity of polyaminoisoprenyl compounds when associated with doxycycline against $S$. Typhimurium. Nevertheless, since the mechanism of action of these compounds remained unclear, we undertook to perform four different experiments to determine how derivative $\mathbf{5 r}$ (as a Z/E mixture) targeted our Gram-negative E. aerogenes EA289 bacteria model, a kanamycinesusceptible derivative of the MDR clinical isolate Ea27. ${ }^{32}$

\section{Mechanism of action}

We have previously determined that compound $\mathbf{5 r}$ strongly decrease the MIC of four antibiotics against MDR Enterobacter and Salmonella strains, and that this activity was not or weakly observed against their isogenic $\triangle A c r A B$ derivatives. This observation suggests that the efflux pump AcrAB-TolC could be the target of the involved compound. Nevertheless, such an inhibition of the efflux pump may result from various actions including either direct interaction with the pump by blocking the antibiotic transfer or competing with the antibiotic during its transfer, by energy disruption or by inhibition of the pump assembly. MIC determination involves the incubation of bacteria in the presence of the selected compound and of the antibiotic for about 18 hours. Thus, the observed synergy may result from the combination of numerous other effects. To eliminate such unwanted observations, we set up a series of real time assays allowing us to follow the interaction of the compound more accurately with the bacteria (Figure 5) 


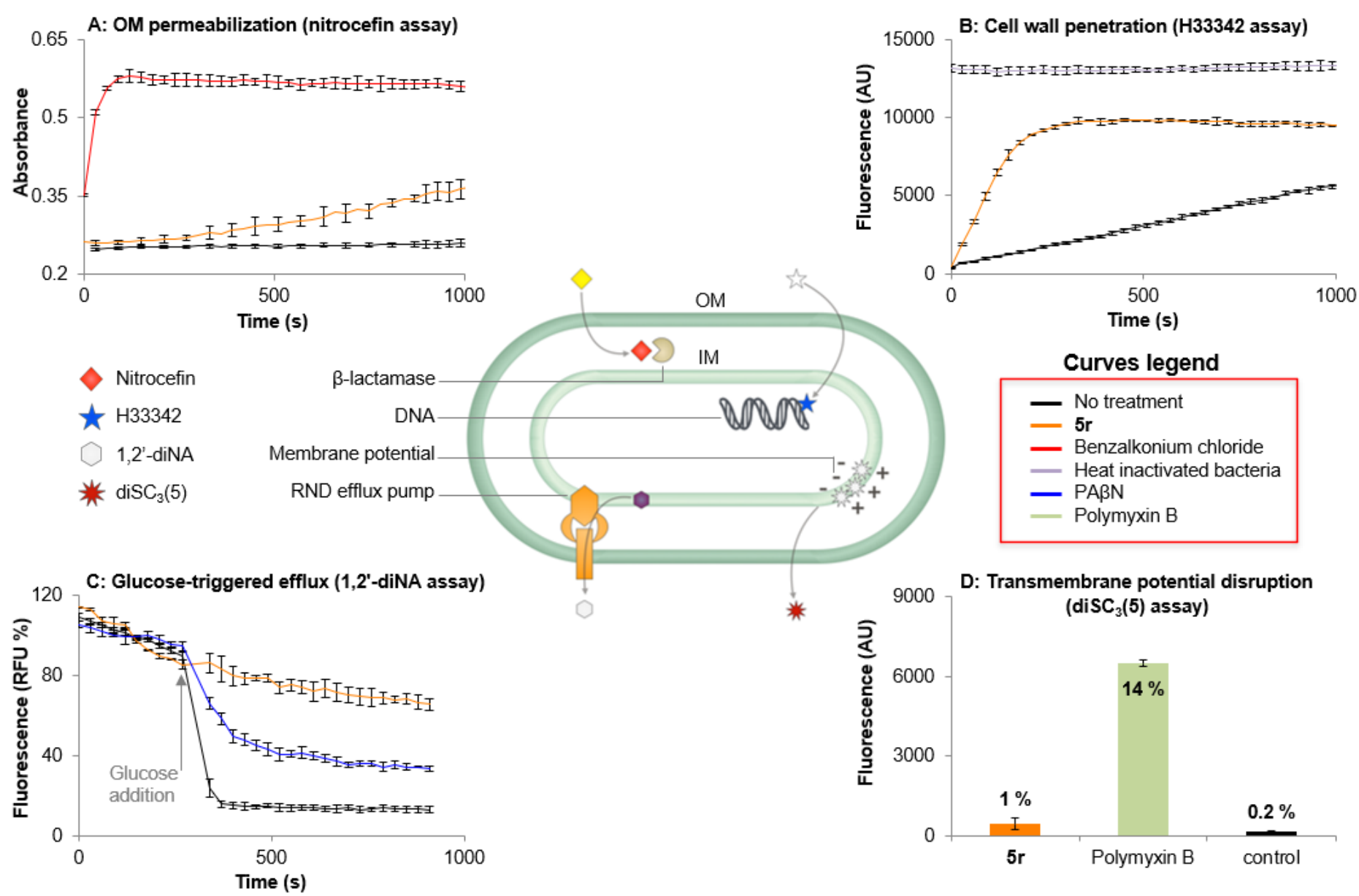

Figure 5. Evaluation of the possible modes of action of $\mathbf{5 r}$ against EA289: A) Outer membrane permeabilization assay by evaluating the rate of nitrocefin hydrolysis. B) H33342 accumulation assay (cell wall penetration) C) Efflux performance of the bacteria by evaluating glucose-triggered 1,2'-diNA efflux. D) Transmembrane potential disruption assay ( $\operatorname{diSC}_{3}(5)$ assay). 
Each experiment was performed using standard molecules as positive control, at a concentration of $100 \mu \mathrm{M} .{ }^{33}$ In a first attempt we have envisioned to determine if a permeabilization and/or disruption of the outer membrane could occur. Thus, outer-membrane permeabilization was followed by monitoring the nitrocefin hydrolysis in the periplasm by the constitutively expressed B-lactamase since an important color change from yellow to red would be observed in the positive. ${ }^{34-35}$ It clearly appears that during the first 200 seconds of incubation, no outer membrane permeabilization was observed by using $\mathbf{5 r}$ whereas in the same time benzalkonium chloride induced a complete outer membrane disruption (Figure 5A). Thus, even after 15 minutes, a slight effect was observed for $\mathbf{5 r}$ without reaching the maximum observed for benzalkonium chloride.

Furthermore, membrane perturbation can also be observed by monitoring H33342 dye entrance into the bacteria (Figure 5B). Fluorescence of this compound correlates with its binding to DNA in the cytoplasm of the bacteria. Thus, even if the H33342 dye entrance occurred in non-treated bacteria, this kinetic is widely increased by adding compound $\mathbf{5 r}$. Taken together, these data suggested that derivative $\mathbf{5 r}$ was unable to strongly disrupt outer membrane integrity but allowed the diffusion of molecules such as H33342 into the bacteria. Furthermore, these observations for nitrocefin and $\mathrm{H} 33342$ are in full agreement with the fact that their respective $\operatorname{LogD}$ are -0.95 and 3.76 suggesting a facilitated diffusion of $\mathrm{H} 33342$ relative to nitrocefin through the membranes of the bacteria. Moreover, since the bacterial strain considered is devoid of porins ${ }^{36}$ which are used by B-lactam compounds such as nitrocefin to cross the outer membrane of Gram-negative bacteria, our results confirm the property of $\mathbf{5 r}$ to disrupt the integrity of the outer membrane and improve its permeability.

On the other hand, we investigated the ability of derivative $\mathbf{5 r}$ to act as an inhibitor of the AcrAB-TolC efflux pump. In this context, the bacteria were loaded with 1,2'dNA dye, a 
substrate of the AcrAB-TolC efflux pump. ${ }^{37}$ Bacteria were then incubated with the compound $(100 \mu \mathrm{M})$ before addition of glucose as energy source. The active transport of $87 \%$ of the dye is observed for non-treated bacteria (Figure 5C, black curve). By using PAßN, a well-known reference for efflux inhibition, a $25 \%$ retention of the dye within the bacterial membranes was observed (Figure 5C, blue curve), whereas addition of derivative $5 \mathbf{r}$ led to a stronger inhibition, resulting in $68 \%$ retention of the dye (Figure $5 \mathrm{C}$, orange curve).

RND efflux pumps, such as the AcrAB-TolC considered here, use the proton gradient across the inner membrane as energy source. Thus, we asked if the efflux inhibition observed in Figure $5 \mathrm{C}$ by $\mathbf{5 r}$, may result in the disruption of the transmembrane potential. For that, we used the membrane potential sensitive probe 3,3'-Dipropylthiadicarbocyanine iodide ( $\left.\operatorname{DiSC}_{3}(5)\right)$ which concentrated across the inner membrane and self-quenched its fluorescence. If a compound impairs the membrane potential, DiSC3(5) is released into the medium leading to a fluorescence increase. Figure 5D summarizes the results obtained by using compound $\mathbf{5 r}$ and polymyxin $\mathrm{B}$, known to strongly disrupt the membrane. A decrease of $14 \%$ of the membrane potential was observed with polymyxin B, while no change was encountered by using compound $\mathbf{5 r}$ suggesting that this later did not inhibit the efflux transport observed in Figure 5C by disrupting the transmembrane potential.

All these data suggest that the observed synergy, between compound $\mathbf{5} \mathbf{r}$ and the tested intracytoplasmic targeted antibiotics, results from a dual effect i.e. a specific OM permeabilization combined with an AcrAB-TolC pump impairment. Thus, although we cannot exclude the impairment of the pump, this latter could be the result of a side effect of the outer membrane permeabilization. Nevertheless, a specific inhibition of AcrAB-TolC remains possible and researches in this regard are under current investigation.

\section{Conclusion}


An original chemical strategy has been developed affording new polyaminoisoprenyl compounds in moderate to good yields. Amongst all the synthetized derivatives, some of them exhibited a strong effect against resistant Gram-negative bacteria of four antibiotics belonging to four different families. Thus, this activity was correlated to the ability of the polyaminoisoprenyl derivatives to alter bacterial outer membrane integrity. Studies are now underway to determine if this restoration of antibiotic susceptibility occurs also by a direct interaction of the molecule with the efflux pump or by another mechanism.

\section{Experimental section}

\subsection{Materials}

All the solvents were purified according to reported procedures, and the reagents used were commercially available. Methanol, ethyl acetate and dichloromethane were purchased from Sigma-Aldrich and used without further purification. Column chromatography was performed on Merck silica gel (70-230 mesh). ${ }^{1} \mathrm{H}$ NMR and ${ }^{13} \mathrm{C}$ NMR spectra were recorded in MeOD on a Bruker AC 300 spectrometer working at $300 \mathrm{MHz}$ and $75 \mathrm{MHz}$, respectively (the usual abbreviations are used: s: singlet, d: doublet, t: triplet, q: quadruplet, m: multiplet). All chemical shifts are given in ppm. Mass spectroscopy analysis has been performed by the Spectropole (Analytical Laboratory) of Aix-Marseille University (Marseille). The purity of the compounds was checked by analytical HPLC (C18 column, eluent $\mathrm{CH}_{3} \mathrm{CN}$-water-TFA (90:10:0.025,v/v/v), 0.5-1 mL/Min) with PDA detector spanning from $210 \mathrm{~nm}$ to $310 \mathrm{~nm}$. All compounds possessed purity above $95 \%$, as determined by analytical HPLC-PDA at $210 \mathrm{~nm}$.

All bacterial experiments were performed on the BAC-Screen platform (UMR-MD1), with a Freedom EVO 150 liquid handling system (Tecan Lyon-France) and were independently repeated at least three times. Antibiotics (chloramphenicol, doxycycline and nalidixic acid) 
were purchased from Sigma (St Quentin Fallavier-France); erythromycin-lactobionate was purchased from Amdipharm ltd (Dublin-Ireland). They were dissolved in ethanol, water or dimethyl sulfoxide (DMSO), as further precised. The chemicals benzalkonium chloride, phenylalanine-arginine beta-naphthylamide (PAßN), polymyxin-B and carbonyl cyanide mchlorophenylhydrazone (CCCP) were purchased from Sigma-Aldrich (St Quentin Fallavier, France). Nitrocefin was purchased from Oxoid (Basingstoke, England), 1,2'Dinaphthylamine (1,2'-diNA) was purchased from T.C.I (Zwijndrecht, Belgium), 3,3' Dipropylthiadicarbocyanine iodide $\left(\operatorname{diSC}_{3}(5)\right)$ was purchased from Anaspec (Freemont, USA), Hoechst 33342 (H33342) was purchased from Molecular probes (Eugene, USA). Benzalkonium chloride, PAßN and polymyxin-B were dissolved in double distilled water and stored at $-20^{\circ} \mathrm{C}$ until use. Nitrocefin was dissolved in DMSO 5\%. 1,2'-diNA, diSC 3 (5), H33342 were dissolved in DMSO 100\%.

\subsection{General procedure for the synthesis of compounds 5a-6r}

The general synthetic pathway is illustrated for the preparation of compound $\mathbf{5 p}$.

A mixture of citral (345 mg, $2.27 \mathrm{mmol})$, titanium(IV)isopropoxide (645 mg, $2.27 \mathrm{mmol}$ ) and spermine $(2.27 \mathrm{mmol})$ in absolute methanol $(5 \mathrm{~mL})$ was stirred at room temperature for 12 hours. Sodium borohydride $(172 \mathrm{mg}, 4.5 \mathrm{mmol})$ was then added at $0^{\circ} \mathrm{C}$ and the resulting mixture was stirred for an additional 2 hours. The reaction was then quenched by adding water $(1 \mathrm{~mL})$. Stirring was maintained at room temperature for 20 minutes. After filtration over a pad of Celite washing with methanol and ethylacetate, the solvents were removed under vaccuum and the crude amine was purified by flash chromatography on silicagel. using $\mathrm{CH}_{2} \mathrm{Cl}_{2} / \mathrm{MeOH} / \mathrm{NH}_{4} \mathrm{OH}$ (7/3/1) as eluent affording the expected coupling product $5 p$ in $64 \%$ yield.

Compound 5a, 49\% yield; Yellow solid; ${ }^{1} \mathrm{H}$ NMR (MeOD): $\delta=5.08-4.90$ (m, 2H), 3.01-2.95 $(\mathrm{m}, 2 \mathrm{H}), 2.68-2.64(\mathrm{~m}, 5 \mathrm{H}), 2.09-2.03(\mathrm{~m}, 3 \mathrm{H}), 1.62-1.40(\mathrm{~m}, 12 \mathrm{H}) .{ }^{13} \mathrm{C}(\mathrm{MeOD}): \delta=142.24$, 
$142.16,132.80,132.78,123.05,116.84,116.78,51.76,51.72,44.19,41.20,31.80,26.20,26.14$, 25.70, 17.80, 17.14. $\mathrm{C}_{12} \mathrm{H}_{24} \mathrm{~N}_{2} \mathrm{~m} / \mathrm{z} 197.1945\left(100 \%,\left(\mathrm{M}+\mathrm{H}^{+}\right)\right)$.

Compound 5b, 33\% yield; Yellow solid; ${ }^{1} \mathrm{H}$ NMR (MeOD): $\delta=5.05-4.93$ (m, 2H), 2.93-2.78 (m, 4H), 2.18-1.92 (m, 5H), 1.63-1.18 (m, 15H). ${ }^{13} \mathrm{C}(\mathrm{MeOD}): \delta=136.20,133.14,124.83$, $120.12,47.18,44.12,40.60,39.17,33.14,26.82,25.38,18.01,17.84 . \mathrm{C}_{13} \mathrm{H}_{26} \mathrm{~N}_{2} \mathrm{~m} / \mathrm{z} 211.2075$ $\left(100 \%,\left(\mathrm{M}+\mathrm{H}^{+}\right)\right)$.

Compound 5e, 61\% yield; Yellow solid; Mixture of Z/E isomers; ${ }^{1} \mathrm{H}$ NMR (MeOD): $\delta=5.08$ $4.82(\mathrm{~m}, 2 \mathrm{H}), 2.95-2.70(\mathrm{~m}, 4 \mathrm{H}), 2.59-2.40(\mathrm{~m}, 6 \mathrm{H}), 2.02-2.00(\mathrm{~m}, 4 \mathrm{H}), 1.83-1.66(\mathrm{~m}, 4 \mathrm{H})$, $1.61-1.51(\mathrm{~m}, 12 \mathrm{H}) .{ }^{13} \mathrm{C}(\mathrm{MeOD}): \delta=142.21,131.83,131.81,122.95,117.35,53.70,51.29$, 48.22 , 44.01, 43.67, 31.78, 27.61, 26.15, 25.82, 23.47, 17.51, 15.92. $\mathrm{C}_{17} \mathrm{H}_{32} \mathrm{~N}_{2} \mathrm{~m} / \mathrm{z} 265.2578$ $\left(100 \%,\left(\mathrm{M}+\mathrm{H}^{+}\right)\right)$.

Compound 5f, 51\% yield; Yellow solid; Mixture of Z/E isomers; ${ }^{1} \mathrm{H}$ NMR (MeOD): $\delta=5.08$ $4.96(\mathrm{~m}, 2 \mathrm{H}), 3.33-2.95(\mathrm{~m}, 8 \mathrm{H}), 2.76-2.71(\mathrm{~m}, 2 \mathrm{H}), 2.23-2.03(\mathrm{~m}, 6 \mathrm{H}), 1.82-1.59(\mathrm{~m}, 12 \mathrm{H})$. ${ }^{13} \mathrm{C}(\mathrm{MeOD}): \delta=177.21,177.15,143.24,141.24,141,21,132.80,123.05,117.32,115.34$, $48.12,48.09,46.94,46.89,44.82,44.01,31.80,31.78,31.09,29.78,28.07,27.52,26.82,19.43$, 18.03, 17.95, 16.45. $\mathrm{C}_{17} \mathrm{H}_{30} \mathrm{~N}_{2} \mathrm{O} \mathrm{m} / \mathrm{z} 279.2364\left(100 \%,\left(\mathrm{M}+\mathrm{H}^{+}\right)\right)$.

Compound 5g, 52\% yield; Yellow solid; ${ }^{1} \mathrm{H}$ NMR (MeOD): $\delta=5.05-4.81$ (m, 2H), 3.51-3.33 (m, 4H), 2.93-2.71 (m, 6H), 2.27-2.01 (m, 6H), 1.62-1.53 (m, 14H). ${ }^{13} \mathrm{C}(\mathrm{MeOD}): \delta=141.84$, $131.75,131,21,123.05,114.32,114.12,66.85,66.79,52.81,51.82,48.19,48.09,43.13,31.79$, 31.09, 27.49, 26.18, 25,23, 17.46, 16.83. $\mathrm{C}_{17} \mathrm{H}_{32} \mathrm{NO} \mathrm{m} / \mathrm{z} 281.2516\left(100 \%,\left(\mathrm{M}+\mathrm{H}^{+}\right)\right)$.

Compound 5j, 42\% yield; Yellow solid; Mixture of Z/E isomers; ${ }^{1} \mathrm{H}$ NMR (MeOD): $\delta=5.04-$ $4.97(\mathrm{~m}, 2 \mathrm{H}), 2.91-2.75(\mathrm{~m}, 5 \mathrm{H}), 2.18-1.97(\mathrm{~m}, 7 \mathrm{H}), 1.67-1.08(\mathrm{~m}, 21 \mathrm{H}) .{ }^{13} \mathrm{C}(\mathrm{MeOD}): \delta=$ $136.77,132.43,131.45,125.41,118.12,55.84,55.54,44.12,39.68,39.45,39.37,38.12,30.60$, 27.07, 26.62, 25.70, 17.18, 16.95, 14.15. $\mathrm{C}_{17} \mathrm{H}_{35} \mathrm{~N}_{3} \mathrm{~m} / \mathrm{z} 282.2846\left(100 \%,\left(\mathrm{M}+\mathrm{H}^{+}\right)\right)$. 
Compound 5k, 49\% yield; Mixture of Z/E isomers, Yellow solid; ${ }^{1} \mathrm{H}$ NMR (MeOD): $\delta=5.15$ $4.95(\mathrm{~m}, 2 \mathrm{H}), 2.97-2.68(\mathrm{~m}, 6 \mathrm{H}), 2.50-2.48(\mathrm{~m}, 4 \mathrm{H}), 2.09-1.98(\mathrm{~m}, 4 \mathrm{H}), 1.68-1.48(\mathrm{~m}, 19 \mathrm{H})$, $0.95(\mathrm{t}, J=6 \mathrm{~Hz}, 6 \mathrm{H}) .{ }^{13} \mathrm{C}(\mathrm{MeOD}): \delta=136.10,136.04,132.80,124.05,123.92,117.32,49.51$, $47.93,47.67,47.30,44.00,40.78,39.68,26.62,25.92,25.70,24.63,17.80,17.03,16.90,16.13$. $\mathrm{C}_{20} \mathrm{H}_{41} \mathrm{~N}_{3} \mathrm{~m} / \mathrm{z} 324.3334\left(100 \%,\left(\mathrm{M}+\mathrm{H}^{+}\right)\right)$.

Compound 5l, 64\% yield; Yellow solid; Mixture of Z/E isomers; ${ }^{1} \mathrm{H}$ NMR (MeOD): $\delta=5.06$ $4.94(\mathrm{~m}, 2 \mathrm{H}), 3.04-2.56(\mathrm{~m}, 16 \mathrm{H}), 2.03-1.99(\mathrm{~m}, 2 \mathrm{H}), 1.64-1.58(\mathrm{~m}, 14 \mathrm{H}) .{ }^{13} \mathrm{C}(\mathrm{MeOD}): \delta=$ $142.32,142.29,131.95,123.05,116.82,51.32,51.24,49.32,48.19,48.03,48.01,44.12,41.12$, $31.79,31.67,26.15,26.10,, 17.75,17.69,16.83 . \mathrm{C}_{16} \mathrm{H}_{34} \mathrm{~N}_{4} \mathrm{~m} / \mathrm{z} 283.2817\left(100 \%,\left(\mathrm{M}+\mathrm{H}^{+}\right)\right)$.

Compound 5n, 58\% yield; Mixture of Z/E isomers, Yellow solid; ${ }^{1} \mathrm{H}$ NMR (MeOD): $\delta=5.07-$ $4.92(\mathrm{~m}, 2 \mathrm{H}), 3.02-2.52(\mathrm{~m}, 27 \mathrm{H}), 2.09-1.58(\mathrm{~m}, 15 \mathrm{H}) .{ }^{13} \mathrm{C}(\mathrm{MeOD}): \delta=141.34,141.29$, $131.77,131.54,124.56,122.95,118.89,117.02,117.01,52.46,51.30,51.14,49.64,48.19$, $48.12,44.15,42.45,41.03,41.01,31.77,26.18,17.96,17.79,16.92 . \mathrm{C}_{20} \mathrm{H}_{44} \mathrm{~N}_{6} \mathrm{~m} / \mathrm{z} 369.3661$ $\left(100 \%,\left(\mathrm{M}+\mathrm{H}^{+}\right)\right)$.

Compound 5p, $64 \%$ yield; Mixture of Z/E isomers, white solid; ${ }^{1} \mathrm{H}$ NMR (MeOD): $\delta=5.27-$ $5.10(\mathrm{~m}, 3 \mathrm{H}), 3.36-3.19(\mathrm{~m}, 4 \mathrm{H}), 2.74-2.63(\mathrm{~m}, 10 \mathrm{H}), 2.12-2.08(\mathrm{~m}, 6 \mathrm{H}), 1.76-1.31(\mathrm{~m}, 22 \mathrm{H})$. ${ }^{13} \mathrm{C}(\mathrm{MeOD}): \delta=140.12,133.18,132.82,125.60,124.18,123.30,50.83,48.38,47.98,47.94$, $41.39,41.22,33.49,30.40,30.30,28.56,27.98,27.95,26.42,26.38,24.14,18.24,16.83$. $\mathrm{C}_{20} \mathrm{H}_{42} \mathrm{~N}_{4} \mathrm{~m} / \mathrm{z} 339.3482\left(100 \%,\left(\mathrm{M}+\mathrm{H}^{+}\right)\right)$.

Compound 5r, 49\% yield; Mixture of Z/E isomers, Yellow solid; ${ }^{1} \mathrm{H}$ NMR (MeOD): $\delta=5.27$ $5.10(\mathrm{~m}, 3 \mathrm{H}), 3.34-3.19(\mathrm{~m}, 4 \mathrm{H}), 2.76-2.53(\mathrm{~m}, 9 \mathrm{H}), 2.12-2.09(\mathrm{~m}, 6 \mathrm{H}), 1.77-1.63(\mathrm{~m}, 20 \mathrm{H})$. ${ }^{13} \mathrm{C}$ (MeOD): $\delta=141.10,140.53,133.66,133.29,125.99,125.90,124.60,123.71,54.95,53.97$, $53.50,49.15,48.42,48.37,41.80,41.60,33.88,30.97,28.37,28.34,26.87-26.48,19.33,18.72$, 17.32. $\mathrm{C}_{19} \mathrm{H}_{40} \mathrm{~N}_{4} \mathrm{~m} / \mathrm{z} 325.3326\left(100 \%,\left(\mathrm{M}+\mathrm{H}^{+}\right)\right)$. 
Compound 6a, 63\% yield; Mixture of Z/E isomers, Yellow solid; ${ }^{1} \mathrm{H}$ NMR (MeOD): $\delta=5.30$ $4.99(\mathrm{~m}, 3 \mathrm{H}), 3.01-2.92(\mathrm{~m}, 2 \mathrm{H}), 2.70-2.67(\mathrm{~m}, 5 \mathrm{H}), 2.09-1.93(\mathrm{~m}, 7 \mathrm{H}), 1.62-1.49(\mathrm{~m}, 15 \mathrm{H})$. ${ }^{13} \mathrm{C}(\mathrm{MeOD}): \delta=140.02,139.84,137.15,137.09,136.12,125.17,124.23,116.80,116.78$, $51.78,51.54,44.19,41.20,39.90,35.48,26.82,26.76,26.32,25.66,23.30,17.62,16.82$. $\mathrm{C}_{17} \mathrm{H}_{32} \mathrm{~N}_{2} \mathrm{~m} / \mathrm{z} 265.2578\left(100 \%,\left(\mathrm{M}+\mathrm{H}^{+}\right)\right)$.

Compound 6b, $49 \%$ yield; Mixture of Z/E isomers, Yellow solid; ${ }^{1} \mathrm{H}$ NMR (MeOD): $\delta=5.18$ $5.01(\mathrm{~m}, 4 \mathrm{H}), 3.22-3.08(\mathrm{~m}, 3 \mathrm{H}), 2.84-2.64(\mathrm{~m}, 4 \mathrm{H}), 2.09-1.90(\mathrm{~m}, 8 \mathrm{H}), 1.66-1.02(\mathrm{~m}, 18 \mathrm{H})$. ${ }^{13} \mathrm{C}(\mathrm{MeOD}): \delta=141.15,141.09,136.77,136.64,136.44,136.33,132.43,132.17,125.41$, $125.37,54.34,47.25,47.17,41.33,40.90,40.80,40.14,32.95,30.53,28.86,27.73,27.77$, $27.65,27.42,26.02,25.97,23.73,17.82,16.52,16.25 . \mathrm{C}_{18} \mathrm{H}_{34} \mathrm{~N}_{2} \mathrm{~m} / \mathrm{z} 279.2745\left(100 \%,\left(\mathrm{M}+\mathrm{H}^{+}\right)\right)$. Compound 6c, 58\% yield; Mixture of Z/E isomers, Yellow solid; ${ }^{1} \mathrm{H}$ NMR (MeOD): $\delta=5.19-$ $4.99(\mathrm{~m}, 3 \mathrm{H}), 2.73-2.56(\mathrm{~m}, 4 \mathrm{H}), 3.32-3.06(\mathrm{~m}, 3 \mathrm{H}), 2.73-2.56(\mathrm{~m}, 4 \mathrm{H}), 2.03-1.80(\mathrm{~m}, 9 \mathrm{H})$, $1.67-1.09(\mathrm{~m}, 20 \mathrm{H}) .{ }^{13} \mathrm{C}(\mathrm{MeOD}): \delta=141.52,141.41,136.54,136.42,132.45,132.24,132.18$ $125.73,125.41,125.37,125.05,121.15,120.11,120.02,54.446,46.88,41.15,40.90,40.80$, $33.38,33.07,32.96,28.79,28.73,27.83,27.41,27.34,26.05,26.00,24.39,23.82,23.76,22.17$, 17.86, 16.60, 16.19. $\mathrm{C}_{19} \mathrm{H}_{36} \mathrm{~N}_{2} \mathrm{~m} / \mathrm{z} 293.2884\left(100 \%,\left(\mathrm{M}+\mathrm{H}^{+}\right)\right)$.

Compound 6d, 38\% yield; Mixture of Z/E isomers, Yellow solid; ${ }^{1} \mathrm{H}$ NMR (MeOD): $\delta=5.28$ $5.11(\mathrm{~m}, 4 \mathrm{H}), 3.43-3.19(\mathrm{~m}, 3 \mathrm{H}), 2.75-2.61(\mathrm{~m}, 4 \mathrm{H}), 2.14-2.06(\mathrm{~m}, 9 \mathrm{H}), 1.77-1.40(\mathrm{~m}, 20 \mathrm{H})$. ${ }^{13} \mathrm{C}(\mathrm{MeOD}): \delta=140.67,140.58,136.61,136.28,132.21,132.15,125.83,125.40,125.37$, $125.13,125.00,121.92,121.28,47.39,41.87,40.89,40.17,33.03,27.83,27.76,27.38,25.94$, 25.55, 23.73, 17.79, 16.45, 16.12. $\mathrm{C}_{20} \mathrm{H}_{38} \mathrm{~N}_{2} \mathrm{~m} / \mathrm{z} 307.3052\left(100 \%,\left(\mathrm{M}+\mathrm{H}^{+}\right)\right)$.

Compound 6e, 71\% yield; Mixture of Z/E isomers, Yellow solid; ${ }^{1} \mathrm{H}$ NMR (MeOD): $\delta=5.14-$ $4.92(\mathrm{~m}, 3 \mathrm{H}), 2.93-2.68(\mathrm{~m}, 6 \mathrm{H}), 2.56-2.48(\mathrm{~m}, 4 \mathrm{H}), 2.09-1.98(\mathrm{~m}, 6 \mathrm{H}), 1.68-1.48(\mathrm{~m}, 21 \mathrm{H})$. ${ }^{13} \mathrm{C}(\mathrm{MeOD}): \delta=140.12,140.00,136.10,136.01,, 124.03,123.92,117.42,54.70,51.38,48.19$, 
$43.27,39.72,31.40,27.50,26.34,25.42,25.34,25.20,23.56,17.62,16.83,15.18 . \mathrm{C}_{22} \mathrm{H}_{40} \mathrm{~N}_{2}$ $\mathrm{m} / \mathrm{z} 333.3194\left(100 \%,\left(\mathrm{M}+\mathrm{H}^{+}\right)\right)$.

Compound 6g, 56\% yield; Mixture of Z/E isomers, Yellow solid; ${ }^{1} \mathrm{H}$ NMR (MeOD): $\delta=5.09$ $4.92(\mathrm{~m}, 3 \mathrm{H}), 2.91-2.61(\mathrm{~m}, 6 \mathrm{H}), 2.56-2.48(\mathrm{~m}, 4 \mathrm{H}), 2.08-1.98(\mathrm{~m}, 6 \mathrm{H}), 1.67-1.46(\mathrm{~m}, 21 \mathrm{H})$. ${ }^{13} \mathrm{C}(\mathrm{MeOD}): \delta=140.32,140.14,139.86,137.61,136.68,132.48,132.25,125.83,125.43$, $125.32,66.70,66.32,53.73,51.92,48.19,44.00,39.37,31.20,27.49,26.82,26.30,25.66$, 17.62, 16.90, 15.84. $\mathrm{C}_{22} \mathrm{H}_{40} \mathrm{~N}_{2} \mathrm{O} \mathrm{m} / \mathrm{z} 349.3120\left(100 \%,\left(\mathrm{M}+\mathrm{H}^{+}\right)\right)$.

Compound 6h, 62\% yield; Mixture of Z/E isomers, Yellow solid; ${ }^{1} \mathrm{H}$ NMR (MeOD): $\delta=5.09$ $4.92(\mathrm{~m}, 3 \mathrm{H}), 2.91-2.61(\mathrm{~m}, 6 \mathrm{H}), 2.56-2.48(\mathrm{~m}, 4 \mathrm{H}), 2.08-1.98(\mathrm{~m}, 6 \mathrm{H}), 1.67-1.46(\mathrm{~m}, 21 \mathrm{H})$. ${ }^{13} \mathrm{C}(\mathrm{MeOD}): \delta=140.11,139.95,137.89,136.58,132.58,132.15,125.99,125.43,125.17$, $52.36,52.03,51.68,51.56,48.19,43.82,40.29,39.77,31.02,27.34,26.82,26.78,26.28,25.89$, 25.66, 24.32, 17.54, 16.90, 15.84. $\mathrm{C}_{25} \mathrm{H}_{48} \mathrm{~N}_{4} \mathrm{~m} / \mathrm{z} 405.3875\left(100 \%,\left(\mathrm{M}+\mathrm{H}^{+}\right)\right)$.

Compound 6i, 52\% yield; Mixture of Z/E isomers, Yellow solid; ${ }^{1} \mathrm{H}$ NMR (MeOD): $\delta=5.17-$ $4.97(\mathrm{~m}, 3 \mathrm{H}), 3.20-3.18(\mathrm{~m}, 4 \mathrm{H}), 2.66-2.54(\mathrm{~m}, 7 \mathrm{H}), 2.02-1.90(\mathrm{~m}, 10 \mathrm{H}), 1.63-1.24(\mathrm{~m}, 24 \mathrm{H})$. ${ }^{13} \mathrm{C}(\mathrm{MeOD}): \delta=140.12,140.00,137.62,136.68,132.58,132.26,125.83,125.43,125.37$, $125.07,47.43,47.28,41.14,40.90,40.78,31.96,28.84,27.78,27.44,26.03,25.99,22.74$, 17.84, 16.57, 16.21. $\mathrm{C}_{21} \mathrm{H}_{41} \mathrm{~N}_{3} \mathrm{~m} / \mathrm{z} 335.3342\left(100 \%,\left(\mathrm{M}+\mathrm{H}^{+}\right)\right)$.

Compound 6j, 58\% yield; Mixture of Z/E isomers, Yellow solid; ${ }^{1} \mathrm{H}$ NMR (MeOD): $\delta=5.29$ $5.14(\mathrm{~m}, 4 \mathrm{H}), 3.34-3.31(\mathrm{~m}, 3 \mathrm{H}), 2.79-2.63(\mathrm{~m}, 4 \mathrm{H}), 2.48-2.45(\mathrm{~m}, 4 \mathrm{H}), 2.26(\mathrm{~s}, 3 \mathrm{H}), 2.14-1.93$ $(\mathrm{m}, 8 \mathrm{H}), 1.77-1.63(\mathrm{~m}, 18 \mathrm{H}) .{ }^{13} \mathrm{C}(\mathrm{MeOD}): \delta=140.97,137.51,137.3,133.23,132.96,126.74$, $126.29,126.24,126.02,125.82,57.79,57.49,50.90,49.16,48.35,43.18,41.75,41.64,29.53$, 28.70, 28.28, 26.88, 26.83, 24.61, 18.70, 17.04. $\mathrm{C}_{22} \mathrm{H}_{43} \mathrm{~N}_{3} \mathrm{~m} / \mathrm{z} 349.3463\left(100 \%,\left(\mathrm{M}+\mathrm{H}^{+}\right)\right)$.

Compound 6m, 32\% yield; Mixture of Z/E isomers, Yellow solid; ${ }^{1} \mathrm{H}$ NMR (MeOD): $\delta=5.12$ $4.89(\mathrm{~m}, 3 \mathrm{H}), 3.05-2.48(\mathrm{~m}, 21 \mathrm{H}), 2.10-1.61(\mathrm{~m}, 23 \mathrm{H}) .{ }^{13} \mathrm{C}(\mathrm{MeOD}): \delta=136.22,136.11$, $135.60,135.45,131.09,125.07,124.66,124.18,116.78,116.67,51.32,49.69,49.62,48.22$, 
$48.06,44.17,39.53,39.03,26.85,26.54,25.89,23.42,17.61,16.82 . \mathrm{C}_{23} \mathrm{H}_{47} \mathrm{~N}_{5} \mathrm{~m} / \mathrm{z} 394.3786$ $\left(100 \%,\left(\mathrm{M}+\mathrm{H}^{+}\right)\right)$.

Compound 6n, 47\% yield; Mixture of Z/E isomers, Yellow solid; ${ }^{1} \mathrm{H}$ NMR (MeOD): $\delta=5.12-$ $4.89(\mathrm{~m}, 3 \mathrm{H}), 3.07-2.53(\mathrm{~m}, 25 \mathrm{H}), 2.11-1.58(\mathrm{~m}, 24 \mathrm{H}) .{ }^{13} \mathrm{C}(\mathrm{MeOD}): \delta=136.57,136.10$ $135.32,135.15,131.09,125.17,124.86,124.78,116.74,116.69,51.39,49.75,49.67,48.19$, $48.16,44.20,41.09,39.78,39.57,26.95,26.32,25.47,23.25,17.52,16.92 . \mathrm{C}_{25} \mathrm{H}_{52} \mathrm{~N}_{6} \mathrm{~m} / \mathrm{z}$ $437.4235\left(100 \%,\left(\mathrm{M}+\mathrm{H}^{+}\right)\right)$.

Compound 6o, $48 \%$ yield; Mixture of Z/E isomers, Yellow solid; ${ }^{1} \mathrm{H}$ NMR (MeOD): $\delta=5.03$ $4.94(\mathrm{~m}, 3 \mathrm{H}), 2.97-2.95(\mathrm{~m}, 2 \mathrm{H}), 2.67-2.2 .61(\mathrm{~m}, 4 \mathrm{H}), 2.01-1.90(\mathrm{~m}, 6 \mathrm{H}), 1.61-1.32(\mathrm{~m}, 37 \mathrm{H})$. ${ }^{13} \mathrm{C}(\mathrm{MeOD}): \delta=136.10,135.00,134.89,131.09,125.17,125.09,124.36,117.24,117.12$, $48.36,44.27,42.60,41.12,34.55,29.67,29.37,28.87,28.45,28.02,27.52,27.49,27.42,23.12$, 17.60, 16.43. $\mathrm{C}_{27} \mathrm{H}_{52} \mathrm{~N}_{2} \mathrm{~m} / \mathrm{z} 405.4110\left(100 \%,\left(\mathrm{M}+\mathrm{H}^{+}\right)\right)$.

Compound 6p, 72\% yield; Yellow solid; ${ }^{1} \mathrm{H}$ NMR (MeOD): $\delta=5.05-4.93$ (m, 3H), 2.93-2.57 (m, 14H), 2.19-1.92 (m, 10H), 1.63-0.97 (m, 23H). ${ }^{13} \mathrm{C}(\mathrm{MeOD}): \delta=142.24,134.83,131.09$, $124.86,124.17,117.32,47.90,47.69,47.64,46.61,44.01,40.60,39.83,33.97,31.20,26.97$, 26.30, 25.66, 25.11, 24.90, 17.62, 16.90, 15.93. $\mathrm{C}_{25} \mathrm{H}_{50} \mathrm{~N}_{4} \mathrm{~m} / \mathrm{z} 407.4033\left(100 \%,\left(\mathrm{M}+\mathrm{H}^{+}\right)\right)$.

Compound 6q, 43\% yield; Yellow solid; Mixture of Z/E isomers, ${ }^{1} \mathrm{H}$ NMR (MeOD): $\delta=5.03$ $4.95(\mathrm{~m}, 3 \mathrm{H}), 3.40-2.88(\mathrm{~m}, 14 \mathrm{H}), 2.17-1.45(\mathrm{~m}, 31 \mathrm{H}) .{ }^{13} \mathrm{C}(\mathrm{MeOD}): \delta=136.20,136.14$, $134.98,134.83,131.02,125.18,125.07,124.84,117.12,70.64,69.07,69.00,68.87$, $46.73,44.25,39.72,39.57,38.86,33.61,27.14,27.09,26.32,25.62,23.33,17.62,16.27$. $\mathrm{C}_{25} \mathrm{H}_{48} \mathrm{~N}_{2} \mathrm{O}_{2} \mathrm{~m} / \mathrm{z} 409.3715\left(100 \%,\left(\mathrm{M}+\mathrm{H}^{+}\right)\right)$.

Compound 6r, 63\% yield; Yellow solid; ${ }^{1} \mathrm{H}$ NMR (MeOD): $\delta=5.03-4.95$ (m, 3H), 2.93-2.64 $(\mathrm{m}, 8 \mathrm{H}), 2.36-1.92(\mathrm{~m}, 14 \mathrm{H}), 1.65-1.39(\mathrm{~m}, 23 \mathrm{H}) .{ }^{13} \mathrm{C}(\mathrm{MeOD}): \delta=142.31,134.93,131.09$ $124.76,124.17,117.39,52.88,51.68,48.19,44.00,40.30,39.33,31.20,30.98,27.67,26.93$, 26.30, 25.66, 17.62, 16.90, 15.32. $\mathrm{C}_{24} \mathrm{H}_{48} \mathrm{~N}_{4} \mathrm{~m} / \mathrm{z} 393.3869\left(100 \%,\left(\mathrm{M}+\mathrm{H}^{+}\right)\right)$. 


\section{Preparation of geranyl chloride (trans (1-Chloro-3,7-dimethyl-octa-2,6-diene)) 7}

To a solution of geraniol $(40.1 \mathrm{~g}, 0.26 \mathrm{~mol})$ and anhydrous $\mathrm{LiCl}(23 \mathrm{~g}, 0.54 \mathrm{~mol})$ in $\mathrm{CH}_{2} \mathrm{Cl}_{2}$ $(250 \mathrm{~mL})$ are added dropwise triethylamine $(50 \mathrm{~mL}, 0.37 \mathrm{~mol})$ and mesyl chloride $(30 \mathrm{~mL}, 0.39$ mol). The reaction is stirred at room temperature for $16 \mathrm{~h}$. and then washed with $10 \% \mathrm{HCl}(2$ x $100 \mathrm{~mL})$, sat. $\mathrm{Na}_{2} \mathrm{CO}_{3}(2 \times 100 \mathrm{~mL})$ and brine $(2 \times 100 \mathrm{~mL})$. The organic layer is dried $\left(\mathrm{Na}_{2} \mathrm{SO}_{4}\right)$ and the solvents removed in vacuo. The crude dark oil is distillated under reduced pressure to afford the pure expected trans 1-Chloro-3,7-dimethyl-octa-2,6-diene as a colorless oil. $27.5 \mathrm{~g}(61 \%) .{ }^{1} \mathrm{H} \mathrm{NMR}\left(\mathrm{CDCl}_{3}, 400 \mathrm{MHz}\right): \delta=5.48-5.43(\mathrm{~m}, 1 \mathrm{H}), 5.10-5.07(\mathrm{~m}, 1 \mathrm{H})$, 4.10-4.12 (d, $J=6.0 \mathrm{~Hz}, 2 \mathrm{H}), 2.14-2.04(\mathrm{~m}, 4 \mathrm{H}), 1.74(\mathrm{~s}, 3 \mathrm{H}), 1.1 .69(\mathrm{~s}, 3 \mathrm{H}), 1.61(\mathrm{~s}, 3 \mathrm{H})$.

\section{Preparation of neryl chloride (cis (1-Chloro-3,7-dimethyl-octa-2,6-diene)) 8}

To a solution of nerol (40.1 g, $0.26 \mathrm{~mol})$ and anhydrous $\mathrm{LiCl}(23 \mathrm{~g}, 0.54 \mathrm{~mol})$ in $\mathrm{CH}_{2} \mathrm{Cl}_{2}(250$ $\mathrm{mL})$ are added dropwise triethylamine $(50 \mathrm{~mL}, 0.37 \mathrm{~mol})$ and mesyl chloride $(30 \mathrm{~mL}, 0.39$ mol). The reaction is stirred at room temperature for $16 \mathrm{~h}$. and then washed with $10 \% \mathrm{HCl}(2$ x $100 \mathrm{~mL})$, sat. $\mathrm{Na}_{2} \mathrm{CO}_{3}(2 \times 100 \mathrm{~mL})$ and brine $(2 \times 100 \mathrm{~mL})$. The organic layer is dried $\left(\mathrm{Na}_{2} \mathrm{SO}_{4}\right)$ and the solvents removed in vacuo. The crude dark oil is distillated under reduced pressure to afford the pure expected cis 1-Chloro-3,7-dimethyl-octa-2,6-diene $\mathbf{8}$ as a colorless oil. $26 \mathrm{~g}(58 \%) .{ }^{1} \mathrm{H} \mathrm{NMR}\left(\mathrm{CDCl}_{3}, 400 \mathrm{MHz}\right): \delta=5.40-5.35(\mathrm{~m}, 1 \mathrm{H}), 5.01-4.99(\mathrm{~m}, 1 \mathrm{H}), 4.04-$ $4.02(\mathrm{~d}, J=8.0 \mathrm{~Hz}, 2 \mathrm{H}), 2.04-1.97(\mathrm{~m}, 4 \mathrm{H}), 1.66(\mathrm{~s}, 3 \mathrm{H}), 1.62(\mathrm{~s}, 3 \mathrm{H}), 1.53(\mathrm{~s}, 3 \mathrm{H}) .{ }^{13} \mathrm{C} \mathrm{NMR}$ $\left(\mathrm{CDCl}_{3}, 75 \mathrm{MHz}\right): \delta=142.69,131.90,123.55,120.27,41.08,39.41,26.19,26.52,17.64$ 16.04.

\section{Scale-up synthesis of cis-5r tartrate salt}


To a solution of tris-(3-aminopropyl)amine $(50 \mathrm{~mL}, 0.25 \mathrm{~mol})$ and triethylamine $(60 \mathrm{~mL}, 0.44$ mol) in distillated THF (100 mL) is added dropwise neryl chloride 8 (35 g, $0.20 \mathrm{~mol})$ in distillated THF $(200 \mathrm{~mL})$. The reaction mixture is stirred at room temperature for $24 \mathrm{~h}$. and evaporated to dryness. The crude residue is purified by column chromatography (eluant $\mathrm{CH}_{2} \mathrm{Cl}_{2} / \mathrm{MeOH} /$ conc. $\left.\mathrm{NH}_{4} \mathrm{OH}, 7: 3: 1\right)$ to afford the pure desired cis \{3-[Bis-(3-amino-propyl)amino]-propyl \}-(3,7-dimethyl-octa-2,6-dienyl)-amine 5r as a pale yellow oil. $31.1 \mathrm{~g}$ (48\%). Then, a solution of cis \{3-[Bis-(3-amino-propyl)-amino]-propyl\}-(3,7-dimethyl-octa-2,6dienyl)-amine $5 \mathbf{r}(23.1 \mathrm{~g}, 0.07 \mathrm{~mol})$ and tartaric acid $(42.8 \mathrm{~g}, 0.28 \mathrm{~mol})$ in anhydrous methanol $(200 \mathrm{ml})$ is stirred at room temperature for $16 \mathrm{~h}$. Methanol is evaporated until residual volume of about $50 \mathrm{~mL}$ is reached. Diethyl ether is added (about $500 \mathrm{~mL}$ ) and the resulting precipitate is filtered off to give the pure desired salt as a white solid. $48.4 \mathrm{~g}(74 \%) .{ }^{1} \mathrm{H}$ NMR $\left(\mathrm{D}_{2} \mathrm{O}, 400\right.$ $\mathrm{MHz}): \delta=5.24-5.20(\mathrm{~m}, 1 \mathrm{H}), 5.10(\mathrm{~m}, 1 \mathrm{H}), 4.50(\mathrm{~s}, 6 \mathrm{H}), 3.66-3.61(\mathrm{~m}, 2 \mathrm{H}), 3.30-3.24(\mathrm{~m}$,

$6 \mathrm{H}), 3.06-3.02(\mathrm{~m}, 6 \mathrm{H}), 2.10(\mathrm{~m}, 9 \mathrm{H}), 1.75(\mathrm{~s}, 3 \mathrm{H}), 1.63(\mathrm{~s}, 3 \mathrm{H}), 1.56(\mathrm{~s}, 3 \mathrm{H}) .{ }^{13} \mathrm{C}$ NMR $\left(\mathrm{D}_{2} \mathrm{O}\right.$, $75 \mathrm{MHz}): \delta=146.96,134.12,123.34,113.42,72.75,49.86,45.00,43.04,36.37,31.31,25.58$, 24.82, 22.62, 21.49, 16.69. MS (ESI) $\mathrm{C}_{19} \mathrm{H}_{40} \mathrm{~N}_{4} \mathrm{~m} / \mathrm{z} 325.4\left(100 \%,\left(\mathrm{M}+\mathrm{H}^{+}\right)\right)$.

\section{Scale-up synthesis of trans-5r}

To a solution of tris-(3-aminopropyl)amine $(50 \mathrm{ml}, 0.25 \mathrm{~mol})$ and triethylamine $(60 \mathrm{~mL}, 0.44$ mol) in distillated THF (100 mL) is added dropwise geranyl chloride 7 (35 g, $0.20 \mathrm{~mol})$ in distillated THF $(200 \mathrm{~mL})$. The reaction mixture is stirred at room temperature for $24 \mathrm{~h}$. and evaporated to dryness. The crude residue is purified by column chromatography (eluant $\mathrm{CH}_{2} \mathrm{Cl}_{2} / \mathrm{MeOH} /$ conc. $\left.\mathrm{NH}_{4} \mathrm{OH}, 7: 3: 1\right)$ to afford the pure desired trans \{3-[Bis-(3-amino-propyl)amino]-propyl -(3,7-dimethyl-octa-2,6-dienyl)-amine 5r as a pale yellow oil. $35.2 \mathrm{~g}(54 \%) .{ }^{1} \mathrm{H}$ NMR (MeOD, $400 \mathrm{MHz}): \delta=5.30(\mathrm{t}, \mathrm{J}=7.0 \mathrm{~Hz}, 1 \mathrm{H}), 5.14(\mathrm{t}, J=6.9 \mathrm{~Hz}, 1 \mathrm{H}), 3.39(\mathrm{~d}, J=$ $7.0 \mathrm{~Hz}, 2 \mathrm{H}), 2.85(\mathrm{t}, J=7.2 \mathrm{~Hz}, 4 \mathrm{H}), 2.75(\mathrm{t}, J=7.4 \mathrm{~Hz}, 2 \mathrm{H}), 2.58(\mathrm{t}, J=6.9 \mathrm{~Hz}, 4 \mathrm{H}), 2.56(\mathrm{t}$, 
$J=7.0 \mathrm{~Hz}, 2 \mathrm{H}), 2.08-2.18(\mathrm{~m}, 4 \mathrm{H}), 1.93(\mathrm{~s}, 3 \mathrm{H}), 1.73-1.80(\mathrm{~m}, 6 \mathrm{H}), 1.73(\mathrm{~s}, 3 \mathrm{H}), 1.71(\mathrm{~s}, 3 \mathrm{H})$, $1.64(\mathrm{~s}, 3 \mathrm{H}) .{ }^{13} \mathrm{C}$ NMR (MeOD, $\left.75 \mathrm{MHz}\right): \delta=177.01,143.60,133.51,125.79,120.49,72.75$, $53.46,53.25,48.28,47.78,41.59,40.88,28.32,28.25,26.89,26.78,25.25,18.66,17.40 . \mathrm{MS}$ (ESI) $\mathrm{C}_{19} \mathrm{H}_{40} \mathrm{~N}_{4} \mathrm{~m} / \mathrm{z} 325.4\left(100 \%,\left(\mathrm{M}+\mathrm{H}^{+}\right)\right)$.

\section{Scale-up synthesis of trans-5r tartrate salt}

A solution of trans \{3-[Bis-(3-amino-propyl)-amino]-propyl\}-(3,7-dimethyl-octa-2,6-dienyl)amine $5 r(23.1 \mathrm{~g}, 0.07 \mathrm{~mol})$ and tartaric acid (42.8 g, $0.28 \mathrm{~mol})$ in anhydrous methanol (200 $\mathrm{mL}$ ) is stirred at room temperature for $16 \mathrm{~h}$. Methanol is evaporated until residual volume of about $50 \mathrm{~mL}$ is reached. Diethyl ether is added (about $500 \mathrm{~mL}$ ) and the resulting precipitate is filtered off to give the pure desired salt as a white solid. $50.1 \mathrm{~g}(76 \%) .{ }^{1} \mathrm{H}$ NMR $\left(\mathrm{D}_{2} \mathrm{O}, 250\right.$ $\mathrm{MHz}): \delta=5.17(\mathrm{~m}, 1 \mathrm{H}), 5.06(\mathrm{~m}, 1 \mathrm{H}), 4.48(\mathrm{~s}, 5 \mathrm{H}), 3.61-3.58(\mathrm{~d}, J=7.3 \mathrm{~Hz}, 2 \mathrm{H}), 3.24-3.20$ (m, 6H), 3.04-2.97 (m, 6H), $2.03(\mathrm{~m}, 10 \mathrm{H}), 1.62(\mathrm{~s}, 3 \mathrm{H}), 1.58(\mathrm{~s}, 3 \mathrm{H}), 1.51$ (s, 3H). ${ }^{13} \mathrm{C}$ NMR $\left(\mathrm{D}_{2} \mathrm{O}, 62.5 \mathrm{MHz}\right): \delta=177.05,147.84,134.29,124.39,113.47,73.48,67.19$ (reference: $1,4-$ dioxane), 50.49, 45.72, 43.68, 39.43, 37.09, 26.11, 25.51, 22.14, 21.24, 17.61, 16.36. MS (ESI) $\mathrm{C}_{19} \mathrm{H}_{40} \mathrm{~N}_{4} \mathrm{~m} / \mathrm{z} 325.4\left(100 \%,\left(\mathrm{M}+\mathrm{H}^{+}\right)\right)$.

\subsection{Bacterial strains and growth conditions}

Four bacterial strains were used in this study. The Enterobacter aerogenes Ea289 strain is a $\mathrm{Kan}^{\mathrm{s}}$ derivative of the MDR clinical isolate Ea27 isolated from a patient and multiresistant. This parent strain was determined to be common to several site of nosocomial infections amongst different Intensive Care units in France. ${ }^{38}$ To allow genetic modification (mutagenesis of AcrAB and of TolC coding genes) the kanamycin resistance from EA27 was removed by plasmid elimination giving EA289. The $a c r B$ mutant Ea289 $\triangle a c r B$ strain was then constructed from the Ea289 strain. $^{32}$ 
The Salmonella enterica serovar Typhimurium strain BN10055 and its $\triangle a c r B$ derivative were previously described..$^{31}$ The strains were maintained at $-80^{\circ} \mathrm{C}$ in $15 \%(\mathrm{v} / \mathrm{v})$ glycerol for cryoprotection. Bacteria were routinely grown in Mueller-Hinton (MHII) broth at $37^{\circ} \mathrm{C}$.

\subsection{Antibiotic susceptibility testing}

Susceptibilities to antibiotics and compounds were determined in microplates by the standard broth dilution method in accordance with the recommendations of the Comité de 1'Antibiogramme de la Société Française de Microbiologie (CA-SFM). ${ }^{22}$ Briefly, the minimal inhibitory concentrations (MICs) were determined with an inoculum of $10^{5} \mathrm{CFU}$ in $200 \mu \mathrm{L}$ of MH broth containing two-fold serial dilutions of each molecule. The MIC was defined as the lowest concentration of a molecule that completely inhibited visible growth after incubation for 18 hours at $37^{\circ} \mathrm{C}$. Compounds were all solubilized in DMSO at high concentration, in order to apply up to 5\% DMSO on bacteria. This concentration did not detrimentally affect bacterial growth of the strains used in this study. All MIC determinations were repeated at least three times in independent experiments.

\subsection{Effect of compounds on antibiotic resistance}

Each compound was tested for its ability to reduce antibiotic resistance. It was assayed at MIC/4 in order to avoid a direct killing effect on bacteria. The MIC of the antibiotics supplemented with the compound was compared to the MIC of the antibiotic alone. For each strain, the ratio of the MIC of an antibiotic tested alone, to its MIC obtained in the presence of the compound determined the MIC ratio. Compounds allowing a MIC ratio $\geq 4$ were considered as efficient synergistic agents with the antibiotic considered on the strain tested.

\subsection{Membrane depolarization assays}


Bacteria were re-suspended at $\mathrm{OD}_{600 \mathrm{~nm}}=0.25$ in Hepes $5 \mathrm{mM}$, EDTA $10 \mathrm{mM} \mathrm{pH} 7.0$ and then washed in Hepes $5 \mathrm{mM}$ pH 7.0 with 3-3'-Dipropylthiadicarbocyanin iodide $\left(\operatorname{diSC}_{3}(5)\right) 8 \mu \mathrm{M}$. The membrane potential-sensitive cyanine dye $\operatorname{diSC}_{3}(5)$ distributes between cells and the medium depending on the cytoplasmic membrane potential gradient. Released diSC3(5) was quantified by measuring the fluorescence $\left(\lambda_{\mathrm{ex}}=622 \mathrm{~nm} ; \lambda_{\mathrm{em}}=690 \mathrm{~nm}\right) 300 \mathrm{~s}$ after the addition of compound $\mathbf{5 r}(100 \mu \mathrm{M})$. A control experiment was performed for every tested condition where the cells were treated with SDS $0.5 \%$ bacteria to normalize the results. Cell suspension was added at $100 \mu \mathrm{l} /$ well and the fluorescence read every $30 \mathrm{~s}$ at $37^{\circ} \mathrm{C}$. An Infinite M200Pro reader (Tecan) was used. Assays were performed in Greiner Bio-One 96 well plates, ref 675076 (half area, black with solid bottom).

\subsection{Nitrocefin hydrolysis assay}

Bacteria were re-suspended at $\mathrm{OD}_{600 \mathrm{~nm}}=0.25$ in Potassium Phosphate buffer $\mathrm{K}_{2} \mathrm{HPO}_{4} 20 \mathrm{mM}$ $\mathrm{MgCl}_{2} 1 \mathrm{mM}$ pH 7.0 (PPB), supplemented with CCCP $5 \mu \mathrm{M}$. Bacteria were mixed with nitrocefin $50 \mu \mathrm{g} / \mathrm{mL}$ before addition of compound $\mathbf{5 r}(100 \mu \mathrm{M})$. Nitrocefin hydrolysis was followed by monitoring the absorbance $\left(\lambda_{\mathrm{abs}}=490 \mathrm{~nm}\right)$. Cell suspension was added at $100 \mu \mathrm{L}$ per well and the absorbance read every $30 \mathrm{~s}$ at $37^{\circ} \mathrm{C}$. An Infinite M200Pro reader (Tecan) was used. Assays were performed in Greiner Bio-One 96 well plates, ref 675101 (half area, clear with flat bottom).

\subsection{Cell wall penetration}

Bacteria were re-suspended at $\mathrm{OD}_{600} \mathrm{~nm}=0.25$ in PPB supplemented with with CCCP $5 \mu \mathrm{M}$. Bacteria were mixed with $\mathrm{H} 334322.5 \mu \mathrm{M}$ before addition of compound $\mathbf{5 r}(100 \mu \mathrm{M})$. H33342 binding to double stranded DNA was followed by monitoring the fluorescence $\left(\lambda_{\mathrm{ex}}=350 \mathrm{~nm}\right.$; $\left.\lambda_{\mathrm{em}}=450 \mathrm{~nm}\right)$. Cell suspension was added at $100 \mu \mathrm{L}$ per well and the fluorescence read every 
$30 \mathrm{~s}$ at $37^{\circ} \mathrm{C}$. An Infinite M200Pro reader (Tecan) was used. Assays were performed in Greiner Bio-One 96 well plates, ref 675076 (half area, black with solid bottom).

\subsection{Glucose-triggered $1,2^{\prime}$-diNA efflux assays}

Bacteria were grown until the stationary phase was reached, collected by centrifugation, and re-suspended at $\mathrm{OD}_{600 \mathrm{~nm}}=0.25$ in PPB supplemented with CCCP $5 \mu \mathrm{M}$, and incubated overnight with $1,2^{\prime}$-Dinaphthylamine (1,2'-diNA) $32 \mu \mathrm{M}$ at $37^{\circ} \mathrm{C}$. Before addition of compound 5r $(100 \mu \mathrm{M})$, the cells were washed in PPB. Glucose $50 \mathrm{mM}$ was added at $300 \mathrm{~s}$ to initiate bacterial energization. Membrane incorporated 1,2'-diNA was followed by monitoring the fluorescence $\left(\lambda_{\mathrm{ex}}=370 \mathrm{~nm} ; \lambda_{\mathrm{em}}=420 \mathrm{~nm}\right)$. Cell suspension was added at $100 \mu \mathrm{L} / \mathrm{well}$ and the fluorescence read every $30 \mathrm{~s}$ at $37^{\circ} \mathrm{C}$. An Infinite M200Pro reader (Tecan) was used. Assays were performed in Greiner Bio-One 96 well plates, ref 675076 (half area, black with solid bottom).

\subsection{Cytotoxicity assays}

Cytotoxicity assessment was performed on the referenced Chinese Hamster Ovary cell line (CHO-K1, ATCC-LGC Promochem, Molsheim France). Cells were maintained in McCoy's 5A medium (Sigma) supplemented with $10 \%$ foetal calf serum, $1 \mathrm{mM}$ glutamine and penicillinstreptomycin (100 U.mL ${ }^{-1}$ and $10 \mu \mathrm{g} \cdot \mathrm{mL}^{-1}$ respectively) and incubated at $37^{\circ} \mathrm{C}$ in a humidified atmosphere containing $5 \% \mathrm{CO}_{2}$. The cytotoxic effects of compounds were assessed by the colorimetric WST-1 cell proliferation assay. Briefly, a range of compounds concentrations from $30 \mu \mathrm{M}$ to $1200 \mu \mathrm{M}$ was incorporated in triplicate cultures, and cells were incubated at $37{ }^{\circ} \mathrm{C}$ for $24 \mathrm{~h}$. At the end of the incubation period, cultures were submitted to three successive washes in phosphate buffer saline (PBS) and incubated in fresh culture medium containing 10\% WST1 for an additional $30 \mathrm{~min}$. Cell viability was evaluated by the assessment of WST-1 absorbance 
at $450 \mathrm{~nm}$ in a microplate spectrophotometer MRX1 II (Dynex technologies, Chantilly, VA, USA). The Inhibitory Concentration $50 \%$ ( $\mathrm{IC}_{50}$ ) was chosen to evaluate the cytotoxicity of compounds. $\mathrm{IC}_{50}$ was defined as the concentration of compounds that induced a $50 \%$ decrease of viable cells.

\subsection{Animals}

We used 5-6 weeks old female BALB/cByJ mice (SAS Janvier, Le-Genest-St-Isle, France). During all experiments, the mice were housed in a ventilated pressurized cabinet (A-BOX 160, Noroit, Rezé, France) with food and water available ad libitum. All experiments were performed according to the guidelines of the Ethics Committee for animal treatment at the Centre de Recherche de Tours (INRA, UE1277, 37380 Nouzilly). Ethical dossier number $\mathrm{N}^{\circ} 6646$.

\subsection{Model of $S$. Typhimurium mice infection}

To assess the severity of infection with or without treatment 12 mice per groups were infected, followed and sacrificed 1 day $(n=3), 3$ days $(n=3)$ or 7 days $(n=6)$ after inoculation. Six mice were used as controls and six were inoculated with saline. For infection, the animals were anaesthetized using Sevofluranew (Abbott, Rungis, France). Inoculation was performed intraperitoneally by injected $200 \mu \mathrm{L}$ of a bacterial solution $\left(10^{2} \mathrm{CFU} / \mathrm{mL}\right)$ of $S$. Typhimurium then followed, each day, by administration of a saline, doxycycline alone or a doxycycline/5r combination solution (64 mg/Kg for doxycycline and $0.5 \mathrm{mg} / \mathrm{Kg}$ for $\mathbf{5 r}$, respectively). The animals were weighed every day until sacrifice or death. Euthanasia was performed using an overdose of thiopental,

\subsection{In vivo toxicity assay}

6 x 6 Mice weighing around $20 \mathrm{~g}$ were intraperitoneally injected with $200 \mu \mathrm{L}$ of $\mathbf{5 r}$ aqueous solution $(12.5,25,50,100 \mu \mathrm{M})$ or saline. The animals were weighed every day, checked 3 times per day and sacrificed after 48 hours. Euthanasia was performed using an overdose of thiopental.

\section{Authors information}

\section{Corresponding author}


Dr Jean Michel Bolla and Dr Jean Michel Brunel share senior co-authorship.

E-mails: jean-michel.bolla@univ-amu.fr and bruneljm@yahoo.fr

\title{
Acknowledgements
}

We deeply acknowledge C. Di Giorgio from the laboratory of biogenotoxicology and environmental mutagenesis school of Pharmacy (Marseille) for their contribution in the cytotoxicity assays. Financial support (A. L. and C. P.) was from a "maturation" grant ValorPACA (Projet Geraniol).

\section{Supporting Information}

Table S-1: MIC of the different compounds against enterobacteria

Table S-2: Efficiency Parameter (EP) of the different molecules used in the assay

Table S-3. MIC of doxycycline in a synergistic assay involving Z/E-5r mixture, Z-5r, E-5r, Z5r (Hydrochloride salt), Z-5r (tartrate salt) against MDR strain EA289 (Average of 3 experiments)

Table S-4. Molecular formula strings of $\mathbf{8}, Z-5 \mathbf{r}, E-5 \mathbf{r}$ and $\mathbf{6 j}$

Fig. S- $1{ }^{1} \mathrm{H}$ and ${ }^{13} \mathrm{C}$ NMR spectra of nerylchloride 8

Fig. S-2 ${ }^{1} \mathrm{H}$ and ${ }^{13} \mathrm{C}$ of $\mathrm{Z} / \mathrm{E}$ mixture of $\mathbf{5 r}$

Fig. S-3 ${ }^{1} \mathrm{H}$ and ${ }^{13} \mathrm{C}$ of $\mathrm{Z} / \mathrm{E}$ mixture of $\mathbf{6 j}$

Fig. S-4 ${ }^{1} \mathrm{H}$ and ${ }^{13} \mathrm{C}$ of cis-5r

Fig. S-5 ${ }^{1} \mathrm{H}$ and ${ }^{13} \mathrm{C}$ of $c i s-5 r$ tatrate salt

Fig. S- $6{ }^{1} \mathrm{H}$ and ${ }^{13} \mathrm{C}$ of trans-5r

Fig. S- $7{ }^{1} \mathrm{H}$ and ${ }^{13} \mathrm{C}$ of trans-5r tartrate salt

\begin{abstract}
Abbreviations
WHO, World Health Organization; EP, Efficiency Parameter; CHO, Chinese Hamster Ovary; PA $\beta$ N, Phenyl-Arginine-Beta-Naphthylamide
\end{abstract}




\section{References}

1. Fraimow, H. S.; Tsigrelis, C., Antimicrobial resistance in the intensive care unit: mechanisms, epidemiology, and management of specific resistant pathogens. Crit. Care Clin. 2011, 27, 163-205.

2. Page, M. G.; Bush, K., Discovery and development of new antibacterial agents targeting gram-negative bacteria in the era of pandrug resistance: is the future promising? Curr. Opin. Pharmacol. 2014, 18, 91-97.

3. Pierluigi, V.; Maddalena, G.; Sara, T.; Russell, L., Treatment of MDR-gram negative infections in the 21st century: a never ending threat for clinicians. Curr. Opin. Pharmacol. 2015, 24, 30-37.

4. Boucher, H. W.; Taldot, G. H.; Benjamin, D. K.; Bradley, J.; Guidos, R. J.; Jones, R. N.; Murray, B. E.; Bonomo, R. A.; Gilbert, D., 10 x '20 Progress--development of new drugs active against gram-negative bacilli: an update from the infectious diseases society of america. Clin. Infect. Dis. 2013, 56, 1685-1694.

5. Payne, D. J.; Gwynn, M. N.; Holmes, D. J.; Pompliano, D. L., Drugs for bad bugs: confronting the challenges of antibacterial discovery. Nat. Rev. Drug Discov. 2007, 6, 2940.

6. Rice, L. B., Federal funding for the study of antimicrobial resistance in nosocomial pathogens: no ESKAPE. J. Infect. dis. 2008, 197, 1079-1081.

7. Tacconelli, E.; Carrara, E.; Savoldi, A.; Harbarth, S.; Mendelson, M.; Monnet, D. L.; Pulcini, C.; Kahlmeter, G.; Kluytmans, J.; Carmeli, Y.; Ouellette, M.; Outterson, K.; Patel, J.; Cavaleri, M.; Cox, E. M.; Houchens, C. R.; Grayson, M. L.; Hansen, P.; Singh, N.; Theuretzbacher, U.; Magrini, N., Discovery, research, and development of new antibiotics: the WHO priority list of antibiotic-resistant bacteria and tuberculosis. Lancet Infect Dis. 2018, 18, 318-327. 
8. Fernández, L.; Hancock, R. E. W., Adaptive and mutational resistance, role of porins and efflux pumps in drug resistance. Clin. Microbiol. Rev. 2012, 25, 661-681.

9. Nikaido, H.; Pagès, J.-M., Broad-specificity efflux pumps and their role in multidrug resistance of gram-negative bacteria. FEMS Microbiol. Rev. 2012, 36, 340-363.

10. Schweizer, H. P., Understanding efflux in gram-negative bacteria: opportunities for drug discovery. Expert opin. drug discov. 2012, 7, 633-642.

11. Sun, J.; Deng, Z.; Yan, A., Bacterial multidrug efflux pumps: mechanisms, physiology and pharmacological exploitations. Biochem. Biophys. Res. Commun. 2014, 453, 254-267.

12. Nikaido, H., Molecular basis of bacterial outer membrane permeability revisited. Microbiol. Mol. Biol. Rev. 2003, 67, 593-656.

13. Pagès, J. M.; Jamees, C. E.; Winterhalter, M., The porin and the permeating antibiotic: a selective diffusion barrier in gram-negative bacteria. Nat. Rev. Microbiol. 2008, 6, 893903.

14. Douafer, A.; Andrieu, V.; Phanstiel, O.; Brunel, J. M., Antibiotic adjuvants: make antibiotics great again! J. Med. Chem. 2019, 62, 8665-8681.

15. Lorenzi, V.; Muselli, A.; Bernardini, A. F.; Berti, L.; Pagès, J. M.; Amaral, L.; Bolla, J. M., Geraniol restores antibiotic activities against multidrug-resistant isolates from gramnegative species. Antimicrob. Agents Chemother. 2009, 53, 2209-2211.

16. Lieutaud, A.; Guinoiseau, E.; Lorenzi, V.; Giuliani, M. C.; Lome, V.; Brunel, J. M.; Luciani, A.; Casanova, J.; Pages, J. M.; Berti, L.; Bolla, J. M., Inhibitors of antibiotic efflux by AcrAB-TolC in enterobacter aerogenes" Anti-Infective Agents 2013, 11, 168-178.

17. Brunel, J. M.; Lieutaud, A.; Lome, V.; Pagès, J. M.; Bolla, J. M., Polyamino geranic derivatives as new chemosensitizers to combat antibiotic resistant gram-negative bacteria. Bioorg. Med. Chem. 2013, 21, 1174-1179. 
18. Borselli, D.; Brunel, J. M.; Gorgé, O.; Bolla, J. M., Polyamino-isoprenyl derivatives as antibiotic adjuvants and motility inhibitors for bordetella bronchiseptica porcine pulmonary infection treatment. Frontiers Microbiol. 2019, 10, 1771.

19. Borselli, D.; Lieutaud, A.; Thefenne, H.; Garnotel, E.; Pagès, J. M.; Brunel, J. M.; Bolla, J. M., Polyamino-isoprenic derivatives block intrinsic resistance of P. aeruginosa to doxycycline and chloramphenicol in vitro" PLoS One 2016, 11, e0154490.

20. Salmi, C.; Letourneux, Y.; Brunel, J. M., Efficient diastereoselective titanium(IV) reductive amination of ketones. Lett. Org. Chem. 2006, 3, 384-389.

21. Salmi, C.; Letourneux, Y.; Brunel, J. M., Efficient synthesis of various secondary amines through a titanium(IV)isopropoxide-mediated reductive amination of ketones. Lett. Org. Chem. 2006, 3, 396-401.

22. Members of the SFM antibiogram committee. Comité de l'antibiogramme de la société française de microbiologie report 2003. Int. J. Antimicrob. Agents 2003, 21, 364-391.

23. Kügler, R.; Bouloussa, O.; Rondelez, F., Evidence of a charge-density threshold for optimum efficiency of biocidal cationic surfaces. Microbiol. 2005, 15, 1341-1348.

24. Brighente, I. M. C.; Yunes, R. A., The general mechanisms of attack of nitrogen nucleophiles on carbonyl compounds. Facts that determine the change of the rate-pH profiles. J. Braz. Chem. Soc. 1997, 8, 549. 1997, 8, 549-553.

25. Guerra, A.; Lunazzi, L., Conformational studies by dynamic NMR. Trigonal nitrogen inversion and enantiomerization processes in the stereolabile chiral isomers of $\mathrm{N}$ naphthylimines. J. Org. Chem. 1995, 60, 7959-7965.

26. Kayser, R. H.; Pollak, R. M., Intramolecular general base catalysis of schiff base hydrolysis by carboxylate ions. J. Am. Chem. Soc. 1977, 99, 3379-3387. 
27. Rosenberg, S.; Silver, S. M.; Sayer, J. M.; Jencks, W. P., Evidence for two concurrent mechanisms and a kinetically significant proton transfer process in acid-catalyzed Omethyloxime formation. J. Am. Chem. Soc. 1974, 96, 7986-7998.

28. Sayer, J. M.; Peskin, M.; Jencks, W. P., Imine-forming elimination reactions. General base acid catalysis and influence of the nitrogen substituent on rates and equilibria for carbinolamine dehydration. J. Am. Chem. Soc. 1973, 95, 4277-4287.

29. Sayer, J. M.; Pinsky, B.; Schonbrunn, A.; Washtien, W., Mechanism of carbinolamine formation. J. Am. Chem. Soc. 1974, 96, 7998-8009.

30. Williams, I. H., Theoretical modelling of specific solvation effects upon carbonyl addition. J. Am. Chem. Soc. 1987, 109, 6299-6307.

31. Baucheron, S.; Tyler, S.; Boyd, D.; Mulvey, M. R.; Chaslus-Dancla, E.; Cloeckaert, A., AcrAB-tolC direct efflux-mediated multidrug resistance in salmonella enterica serovar typhimurium DT104. Antimicrob. Agents Chemother. 2004, 48, 3729-3735.

32. Mallea, M.; Chevalier, J.; Bornet, C.; Eyraud, A.; Davin-Regli, A.; Bollet, C.; Pagès, J. M., Porin alteration and active efflux: two in vivo drug resistance strategies used by enterobacter. Microbiology 1998, 144, 3003-3009.

33. Misra, R.; Morrison, K. D.; Cho, H. J.; Khuua, T., Importance of real-time assays to distinguish multidrug efflux pump-inhibiting and outer membrane-destabilizing activities in escherichia coli. J. Bacteriol. 2015, 197, 2479-2488.

34. Lomovskaya, O.; Warren, M. S.; Lee, A.; Galazzo, J.; Fronko, R.; Lee, M.; Blais, J.; Cho, D.; Chamberland, S.; Renau, T.; Leger, R.; Hecker, S.; Watkins, W.; Hoshino, K.; Ishida, H.; Lee, V. J., Identification and characterization of inhibitors of multidrug resistance efflux pumps in pseudomonas aeruginosa: novel agents for combination therapy. Antimicrob. Agents Chemother. 2001, 45, 105-116. 
35. Matsumoto, Y.; Hayama, K.; Sakakihara, S.; Nishino, K.; Noji, H.; Lino, R.; Yamaguchi, A., Evaluation of multidrug efflux pump inhibitors by a new method using microfluidic channels. PLoS One 2011, 6, e18547.

36. Pradel, E.; Pagès, J. M., The AcrAB-TolC efflux pump contributes to multidrug resistance in the nosocomial pathogen enterobacter aerogenes. Antimicrob. Agents Chemother. 2002, 46, 2640-2643.

37. Bohnert, J. A.; Schuster, S.; Szymaniak-Vits, M.; Kern, W. V., Determination of real-time efflux phenotypes in Escherichia coli AcrB binding pocket phenylalanine mutants using a 1,2-dinaphthylamine efflux assay. PLoS One 2011, 6, e21196.

38. Bosi, C.; Davin-Regli, A.; Bornet, C.; Mallea, M.; Pages, J. M.; Bollet, C., Most enterobacter aerogenes strains in france belong to a prevalent clone. J. Clin. Microbiol. 1999, 37, 2165-2169. 